Prepared as a part of the

National Water-Quality Assessment (NAWOA) Program

\title{
Environmental Setting of Maple Creek Watershed, Nebraska
}

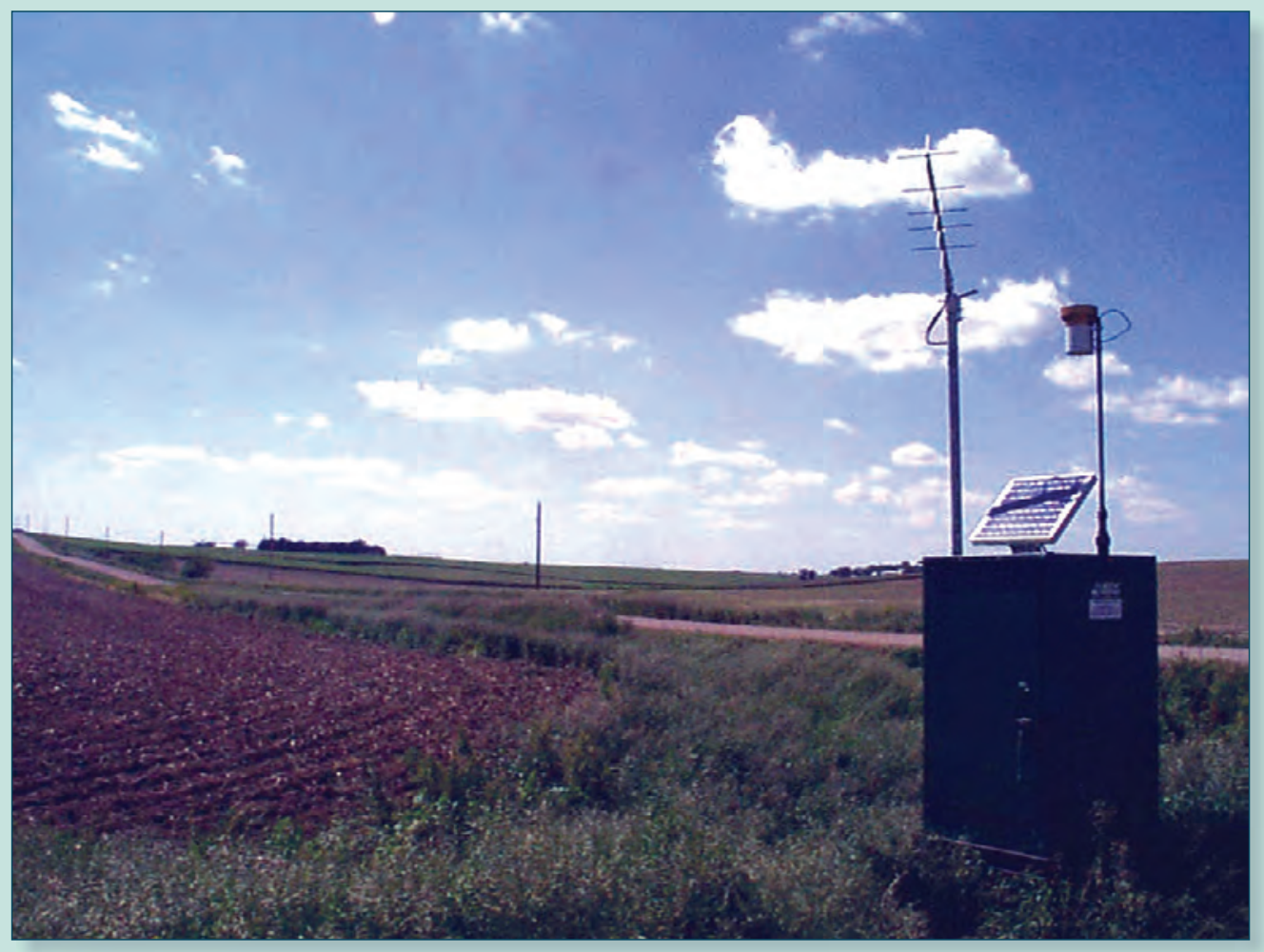

Scientific Investigations Report 2006-5037 
Cover. Photograph showing view looking northwest (upstream) near the U.S. Geological Survey (USGS) gage house located next to an unnamed tributary to South Fork of Dry Creek near Schuyler, Nebraska (station number 06799750) in June 2004.

(Photograph by Jason Vogel, USGS Nebraska Water Science Center, Lincoln, Nebraska.) 


\section{Environmental Setting of Maple Creek Watershed, Nebraska}

By Brian S. Fredrick, Joshua I. Linard, and Jennifer L. Carpenter

Prepared as part of the

National Water-Quality Assessment (NAWQA) Program

Scientific Investigations Report 2006-5037 


\section{U.S. Department of the Interior DIRK KEMPTHORNE, Secretary \\ U.S. Geological Survey \\ P. Patrick Leahy, Acting Director}

\section{U.S. Geological Survey, Reston, Virginia: 2006}

For product and ordering information:

World Wide Web: http://www.usgs.gov/pubprod

Telephone: 1-888-ASK-USGS

For more information on the USGS--the Federal source for science about the Earth, its natural and living resources, natural hazards, and the environment:

World Wide Web: http://www.usgs.gov

Telephone: 1-888-ASK-USGS

Any use of trade, product, or firm names is for descriptive purposes only and does not imply endorsement by the U.S. Government.

Although this report is in the public domain, permission must be secured from the individual copyright owners to reproduce any copyrighted materials contained within this report.

Suggested citation:

Fredrick, B.S., Linard, J.I., and Carpenter, J.L., 2006, Environmental setting of Maple Creek watershed, Nebraska: U.S. Geological Survey Scientific Investigations Report 2006-5037, 22 p. 


\section{Foreword}

The U.S. Geological Survey (USGS) is committed to serve the Nation with accurate and timely scientific information that helps enhance and protect the overall quality of life, and facilitates effective management of water, biological, energy, and mineral resources (http://www.usgs.gov/). Information on the quality of the Nation's water resources is of critical interest to the USGS because it is so integrally linked to the long-term availability of water that is clean and safe for drinking and recreation and that is suitable for industry, irrigation, and habitat for fish and wildlife. Escalating population growth and increasing demands for the multiple water uses make water availability, now measured in terms of quantity and quality, even more critical to the long-term sustainability of our communities and ecosystems.

The USGS implemented the National Water-Quality Assessment (NAWQA) Program to support national, regional, and local information needs and decisions related to water-quality management and policy. (http://water.usgs.gov/nawqa/). Shaped by and coordinated with ongoing efforts of other Federal, State, and local agencies, the NAWQA Program is designed to answer: What is the condition of our Nation's streams and ground water? How are the conditions changing over time? How do natural features and human activities affect the quality of streams and ground water, and where are those effects most pronounced? By combining information on water chemistry, physical characteristics, stream habitat, and aquatic life, the NAWQA Program aims to provide science-based insights for current and emerging water issues and priorities. NAWQA results can contribute to informed decisions that result in practical and effective water-resource management and strategies that protect and restore water quality.

Since 1991, the NAWQA Program has implemented interdisciplinary assessments in more than 50 of the Nation's most important river basins and aquifers, referred to as Study Units (http://water.usgs. gov/nawqa/nawqamap.html). Collectively, these Study Units account for more than 60 percent of the overall water use and population served by public water supply, and are representative of the Nation's major hydrologic landscapes, priority ecological resources, and agricultural, urban, and natural sources of contamination.

Each assessment is guided by a nationally consistent study design and methods of sampling and analysis. The assessments thereby build local knowledge about water-quality issues and trends in a particular stream or aquifer while providing an understanding of how and why water quality varies regionally and nationally. The consistent, multi-scale approach helps to determine if certain types of water-quality issues are isolated or pervasive, and allows direct comparisons of how human activities and natural processes affect water quality and ecological health in the Nation's diverse geographic and environmental settings. Comprehensive assessments on pesticides, nutrients, volatile organic compounds, trace metals, and aquatic ecology are developed at the national scale through comparative analysis of the Study-Unit findings (http://water.usgs.gov/nawqa/natsyn.html).

The USGS places high value on the communication and dissemination of credible, timely, and relevant science so that the most recent and available knowledge about water resources can be applied in management and policy decisions. We hope this NAWQA publication will provide you the needed insights and information to meet your needs, and thereby foster increased awareness and involvement in the protection and restoration of our Nation's waters.

The NAWQA Program recognizes that a national assessment by a single program cannot address all water-resource issues of interest. External coordination at all levels is critical for a fully integrated understanding of watersheds and for cost-effective management, regulation, and conservation of our Nation's water resources. The Program, therefore, depends extensively on the advice, cooperation, and information from other Federal, State, interstate, Tribal, and local agencies, non-government organizations, industry, academia, and other stakeholder groups. The assistance and suggestions of all are greatly appreciated.

Robert M. Hirsch

Associate Director for Water 


\section{Contents}

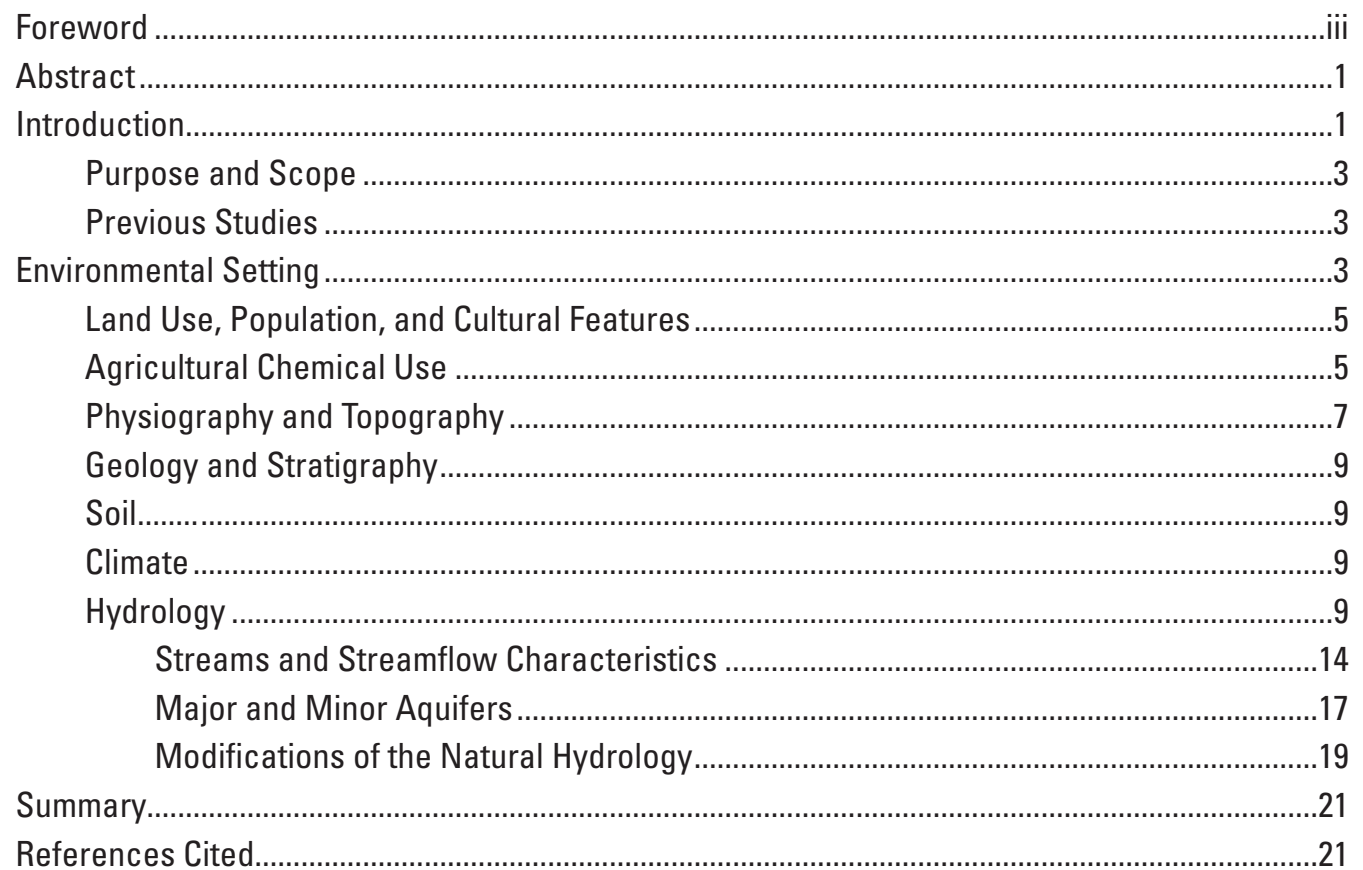

\section{Figures}

1-2. Maps showing-

1. National Water-Quality Assessment (NAWOA) Program Central Nebraska Basins (CNBR) study area and location of the Maple Creek watershed ....................2

2. Land-use and land-cover characteristics in the Maple Creek watershed and the Small watershed, Nebraska...................................................................................

3. Graph showing population of Colfax County, Nebraska, 1900 to 2000 ................................5

4-7. Maps showing-

4. Population density in the Maple Creek watershed, Nebraska ...................................6

5. Topography of the Maple Creek watershed, Nebraska ............................................8

6. Bedrock geologic units within the Maple Creek watershed, Nebraska .................10

7. Soil texture categorized by grain-size distribution in the Maple Creek watershed, Nebraska.

8-9. Generalized block diagrams showing-

8. The Nora-Crofton-Moody soil association and underlying lithology that is typical of upland areas of the Maple Creek watershed, Nebraska .........................13

9. The Zook-Shell-Hobbs soil association and underlying lithology that is typical of lowland areas of the Maple Creek watershed, Nebraska ........................13

10. Graph showing mean monthly precipitation and temperature for Columbus, Nebraska, 1971-2000..

11. Map showing location of USGS stream gages and monitoring wells in the Maple Creek watershed, Nebraska. 
12-16. Graphs showing-

12. Annual mean discharge for Maple Creek near Nickerson, Nebraska, water years 1952 to 2003

13. Daily precipitation at Columbus and discharge at Maple Creek near Nickerson, Nebraska, October 1997 to October 1998

14. Hourly precipitation at the Small watershed and discharge at the Small watershed stream gage (06799750), April to July 2004.

15. Discrete ground-water level measurements for USGS well 413317096455101, June 1968 through April 2004

16. Water levels in wells in the flow path study area near Nickerson, Nebraska, 2004

\section{Tables}

1. Land-use and land-cover characteristics of the Maple Creek watershed and the Small watershed, eastern Nebraska.

2. Agricultural chemical application estimates for the Maple Creek watershed and the Small watershed, eastern Nebraska. 7

3. Stratigraphy and hydrogeology of Maple Creek watershed, eastern Nebraska .11

4. Statistical summary of streamflow at selected sites in the Elkhorn River Basin,

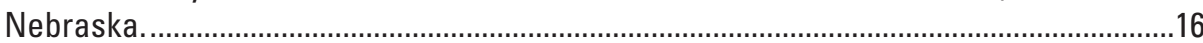

5. Major features of aquifer settings in Maple Creek Valley, eastern Nebraska...........................18 


\section{Conversion Factors and Datums}

\begin{tabular}{|c|c|c|}
\hline Multiply & By & To obtain \\
\hline \multicolumn{3}{|c|}{ Length } \\
\hline centimeter $(\mathrm{cm})$ & 0.03937 & inch (in.) \\
\hline feet $(\mathrm{ft})$ & 0.3048 & meter $(\mathrm{m})$ \\
\hline millimeter $(\mathrm{mm})$ & 0.03937 & inch (in.) \\
\hline meter $(\mathrm{m})$ & 3.281 & foot $(\mathrm{ft})$ \\
\hline kilometer $(\mathrm{km})$ & 0.6214 & mile (mi) \\
\hline \multicolumn{3}{|c|}{ Area } \\
\hline hectare (ha) & 2.471 & acre \\
\hline square kilometer $\left(\mathrm{km}^{2}\right)$ & 247.1 & acre \\
\hline hectare (ha) & 0.003861 & square mile $\left(\mathrm{mi}^{2}\right)$ \\
\hline square kilometer $\left(\mathrm{km}^{2}\right)$ & 0.3861 & square mile $\left(\mathrm{mi}^{2}\right)$ \\
\hline \multicolumn{3}{|c|}{ Volume } \\
\hline cubic meter $\left(\mathrm{m}^{3}\right)$ & 35.31 & cubic foot $\left(\mathrm{ft}^{3}\right)$ \\
\hline cubic meter $\left(\mathrm{m}^{3}\right)$ & 1.308 & cubic yard $\left(\mathrm{yd}^{3}\right)$ \\
\hline cubic kilometer $\left(\mathrm{km}^{3}\right)$ & 0.2399 & cubic mile $\left(\mathrm{mi}^{3}\right)$ \\
\hline cubic meter $\left(\mathrm{m}^{3}\right)$ & 0.0008107 & acre-foot (acre-ft) \\
\hline gallon per minute (gal/min) & 0.06309 & liter per second $(\mathrm{L} / \mathrm{s})$ \\
\hline microgram per liter $(\mu \mathrm{g} / \mathrm{L})$ & 1.0 & part per million (ppm) \\
\hline \multicolumn{3}{|c|}{ Flow rate } \\
\hline cubic meter per second $\left(\mathrm{m}^{3} / \mathrm{s}\right)$ & 70.07 & acre-foot per day (acre-ft/d) \\
\hline cubic meter per second $\left(\mathrm{m}^{3} / \mathrm{s}\right)$ & 35.31 & cubic foot per second $\left(\mathrm{ft}^{3} / \mathrm{s}\right)$ \\
\hline cubic meter per day $\left(\mathrm{m}^{3} / \mathrm{d}\right)$ & 35.31 & cubic foot per day $\left(\mathrm{ft}^{3} / \mathrm{d}\right)$ \\
\hline \multicolumn{3}{|c|}{ Mass } \\
\hline kilogram (kg) & 2.205 & pound avoirdupois (lb) \\
\hline metric ton & 2,205 & pound (lb) \\
\hline
\end{tabular}

Temperature in degrees Celsius $\left({ }^{\circ} \mathrm{C}\right)$ may be converted to degrees Fahrenheit $\left({ }^{\circ} \mathrm{F}\right)$ as follows:

$$
{ }^{\circ} \mathrm{F}=\left(1.8 \times{ }^{\circ} \mathrm{C}\right)+32
$$

Temperature in degrees Fahrenheit $\left({ }^{\circ} \mathrm{F}\right)$ may be converted to degrees Celsius $\left({ }^{\circ} \mathrm{C}\right)$ as follows:

$$
{ }^{\circ} \mathrm{C}=\left({ }^{\circ} \mathrm{F}-32\right) / 1.8
$$

Vertical coordinate information is referenced to the North American Vertical Datum of 1988 (NAVD 88).

Horizontal coordinate information is referenced to the North American Datum of 1983 (NAD 83).

Elevation, as used in this report, refers to distance above the vertical datum.

Water year in USGS reports dealing with surface-water supply is the 12-month period October 1 through September 30. The water year is designated by the calendar year in which it ends and which includes 9 of the 12 months. Thus, the year ending September 30, 2005, is called the "2005 water year."

NOTE TO USERS: Use of hectare (ha) as an alternative name for square hectometer $\left(\mathrm{hm}^{2}\right)$ is restricted to the measurement of small land or water areas. 


\title{
Environmental Setting of Maple Creek Watershed, Nebraska
}

\author{
By Brian S. Fredrick, Joshua I. Linard, and Jennifer L. Carpenter
}

\section{Abstract}

The Maple Creek watershed covers a 955-squarekilometer area in eastern Nebraska, which is a region dominated by agricultural land use. The Maple Creek watershed is one of seven areas currently included in a nationwide study of the sources, transport, and fate of water and chemicals in agricultural watersheds. This study, known as the topical study of "Agricultural Chemicals: Sources, Transport, and Fate" is part of the National Water-Quality Assessment Program being conducted by the U.S. Geological Survey. The Program is designed to describe water-quality conditions and trends based on representative surface- and ground-water resources across the Nation. The objective of the Agricultural Chemicals topical study is to investigate the sources, transport, and fate of selected agricultural chemicals in a variety of agriculturally diverse environmental settings. The Maple Creek watershed was selected for the Agricultural Chemicals topical study because its watershed represents the agricultural setting that characterizes eastern Nebraska. This report describes the environmental setting of the Maple Creek watershed in the context of how agricultural practices, including agricultural chemical applications and irrigation methods, interface with natural settings and hydrologic processes. A description of the environmental setting of a subwatershed within the drainage area of Maple Creek is included to improve the understanding of the variability of hydrologic and chemical cycles at two different scales.

\section{Introduction}

A watershed is the contributing drainage area associated with a surface-water body, the characteristics of which can define or help explain streamflow or water-level changes, water-quality trends, and ecological integrity of the water body. The Maple Creek watershed, in eastern Nebraska (fig. 1), is one of seven watersheds that were selected to represent nationally important agricultural settings. These agricultural settings are defined by the combination of crop type, animal production, and agricultural management practices that are common in a region. Other watersheds selected for this study are located in California, Washington, Iowa, Mississippi, Indiana, and Maryland. The Agricultural Chemicals Team (ACT) examined these seven watersheds as part of the "Agricultural Chemicals: Sources, Transport, and Fate" topical study being conducted for the U.S. Geological Survey (USGS) National Water-Quality Assessment (NAWQA) Program. The NAWQA Program is designed to describe water-quality conditions and trends based on representative surface- and ground-water resources across the Nation and to increase the understanding of the factors that affect those conditions and trends (Gilliom and others, 2001). The Maple Creek watershed covers a $955-\mathrm{km}^{2}$ (square kilometers) area and is part of the larger Central Nebraska Basins (CNBR) study unit of the NAWQA Program, which is about $77,700 \mathrm{~km}^{2}$ (fig. 1). The goal of the ACT study is to investigate the sources, transport, and fate of selected agricultural chemicals in various agricultural settings and at varying scales across the Nation. The primary objective of the nationwide ACT study is to describe and understand the relation between sources of water and agricultural chemicals (nutrients and pesticides) and their behavior and transport through the environment in the context of watershed-scale processes (U.S. Geological Survey, 2003). One of the components of this nationwide study is to examine watershed processes at two scales. The two scales examined in this local study are represented by the Maple Creek watershed and a small $1.5-\mathrm{km}^{2}$ subwatershed, referred to in this report as the Small watershed, located within the drainage area of Maple Creek.

Maple Creek was selected as an indicator station for the ACT study because, among existing CNBR sampling stations, its watershed represents the agricultural setting that typifies eastern Nebraska's corn and soybean production. Agricultural land use in this area is intensive because of the soil type and climatic features of the region, which are conducive to corn and soybean production. To ensure successful crop growth and marketable yields, natural processes are sometimes augmented or inhibited by the addition of chemical fertilizers and the use of chemical herbicides that attenuate the growth of weeds and other undesirable plants. Previous NAWQA investigations and routine water-quality sampling have indicated that agricultural practices, including the use of agricultural chemicals, are 


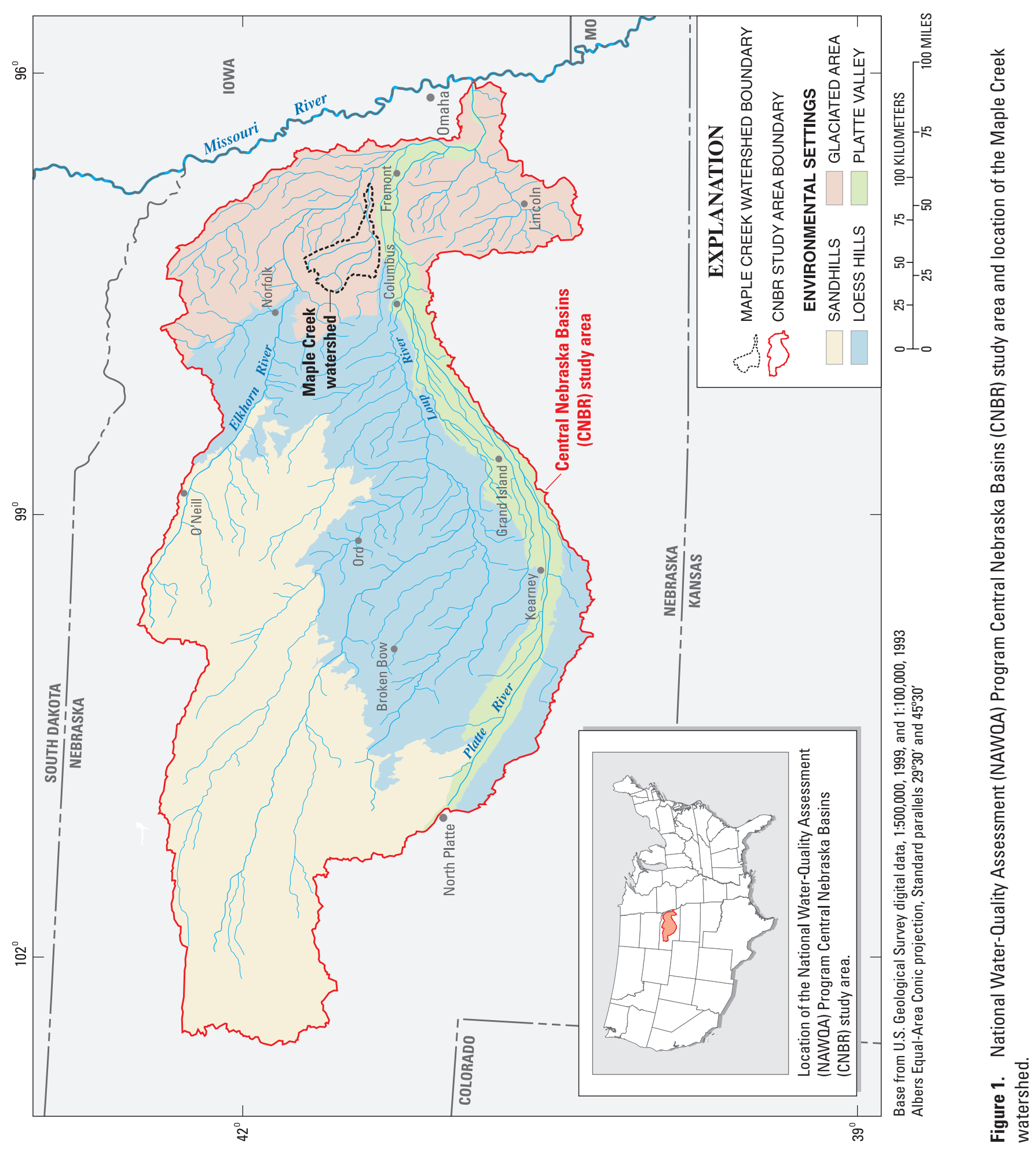


important factors in determining water-quality conditions in the CNBR and Maple Creek study areas (Frenzel and others, 1998). During the ACT study of Maple Creek, the hydrologic system and related processes were observed and monitored to assess hydrologic and chemical conditions in an environment dominated by agricultural land-use practices.

In addition to monitoring and assessing hydrologic and chemical conditions in the Maple Creek watershed, the Small watershed, an unnamed tributary to South Fork of Dry Creek, was also studied intensively. The Small watershed is located in Colfax County, Nebraska (fig. 2). The Small watershed was selected for intensive water-quality monitoring and observation of hydrologic processes because of its homogeneous land-use characteristics. Data collected from the Small watershed will be compared to data collected in the larger Maple Creek watershed to assess hydrologic processes at two different scales.

\section{Purpose and Scope}

The purpose of this report is to describe the environmental setting of the Maple Creek watershed in the context of how agricultural practices are integrated with natural settings and hydrologic processes. A description of the physical, geographical, and agricultural setting is included. One objective of this report is to describe the environmental setting of both the Maple Creek watershed and the Small watershed. Some comparisons are made between the two different-sized watersheds with respect to agricultural chemical application rates, land-use characteristics, and hydrologic processes. This report is intended to be a reference document for subsequent reports that will examine hydrologic processes and agricultural chemical transport in this region.

\section{Previous Studies}

Regional and statewide studies have documented the usage, occurrence, and distribution of agricultural chemicals in settings similar to those found in the Maple Creek watershed. Herbicides, insecticides, and fertilizers are commonly used to maximize yields and sustain productivity of cropland across Nebraska. Approximately 81 percent of the more than 10,432 metric tons of active herbicide ingredients and 96 percent of the 2,177 metric tons of active insecticide ingredients used in the State in 1987 were applied to corn (Baker and others, 1990). The pesticides commonly associated with corn production (atrazine, cyanazine, and metolachlor) were detected more often in samples from Maple Creek during 1992-1995 than at other surface-water sampling sites in the Platte River Basin (Stamer and Wieczorek, 1995). This occurrence was explained as being a function of the greater relative extent of cropland in the Maple Creek watershed than for the Platte River Basin.
In a statewide study, logistic regression models were used to predict atrazine concentrations in 268 ground-water wells (Druliner and others, 1996). These models correctly identified the presence or absence of atrazine 80 percent of the time by using explanatory variables such as: slope of the potentiometric surface; drainage and permeability of soils and aquifer materials; distance the atrazine was transported through the unsaturated zone to reach the water table; and the spatial extent of irrigation development (Druliner and others, 1996). In another study (Spalding and others, 1989), 2,263 wells in agricultural areas of Nebraska were sampled for pesticides. Wells in irrigated corn-growing areas with an average water table that was less than $15 \mathrm{~m}$ (meters) below land surface had the highest frequency of detections. Atrazine was detected in 305 of the 2,263 wells. Of the 305 wells sampled, 22 had concentrations of atrazine greater than $3.0 \mu \mathrm{g} / \mathrm{L}$ (micrograms per liter), which is the maximum contaminant level of regulatory concern for safe drinkingwater supplies (Spalding and others, 1989).

The CNBR study unit has been characterized as having four distinct environmental settings - the Sandhills, the Glaciated Area (which includes the Maple Creek watershed), the Loess Hills, and the Platte Valley (Huntzinger and Ellis, 1993). According to statistical analyses performed on samples collected before 1991, nutrient concentrations varied significantly among the environmental settings. Median concentrations of total nitrogen, nitrate, total phosphorus, and dissolved phosphorus at surface-water sites were elevated in the Loess Hills and the Glaciated Area, including the upper parts of the Maple Creek watershed as compared with those in the Platte Valley. In addition, median concentrations of nitrate in the Platte Valley and dissolved phosphorus in the Sandhills in shallow ground water were higher than in other environmental settings in the CNBR (Helgesen and others, 1994).

\section{Environmental Setting}

The physical, chemical, hydrologic, and ecological characteristics of an area are considered to compose its environmental setting (Stark and others, 1996). The combination and dynamic interaction of hydrologic, geologic, physiographic, water-use, and land-use characteristics in a particular environmental setting can explain the quality of water resources in a region. Combinations of these characteristics also can be related to the potential for the contamination of surface and ground water and may explain regional waterquality differences or similarities (Huntzinger and Ellis, 1993). The environmental setting of any study area provides a reference for conceptualizing the hydrologic system being studied, and provides a better understanding of physical and chemical processes occurring within the study area. 

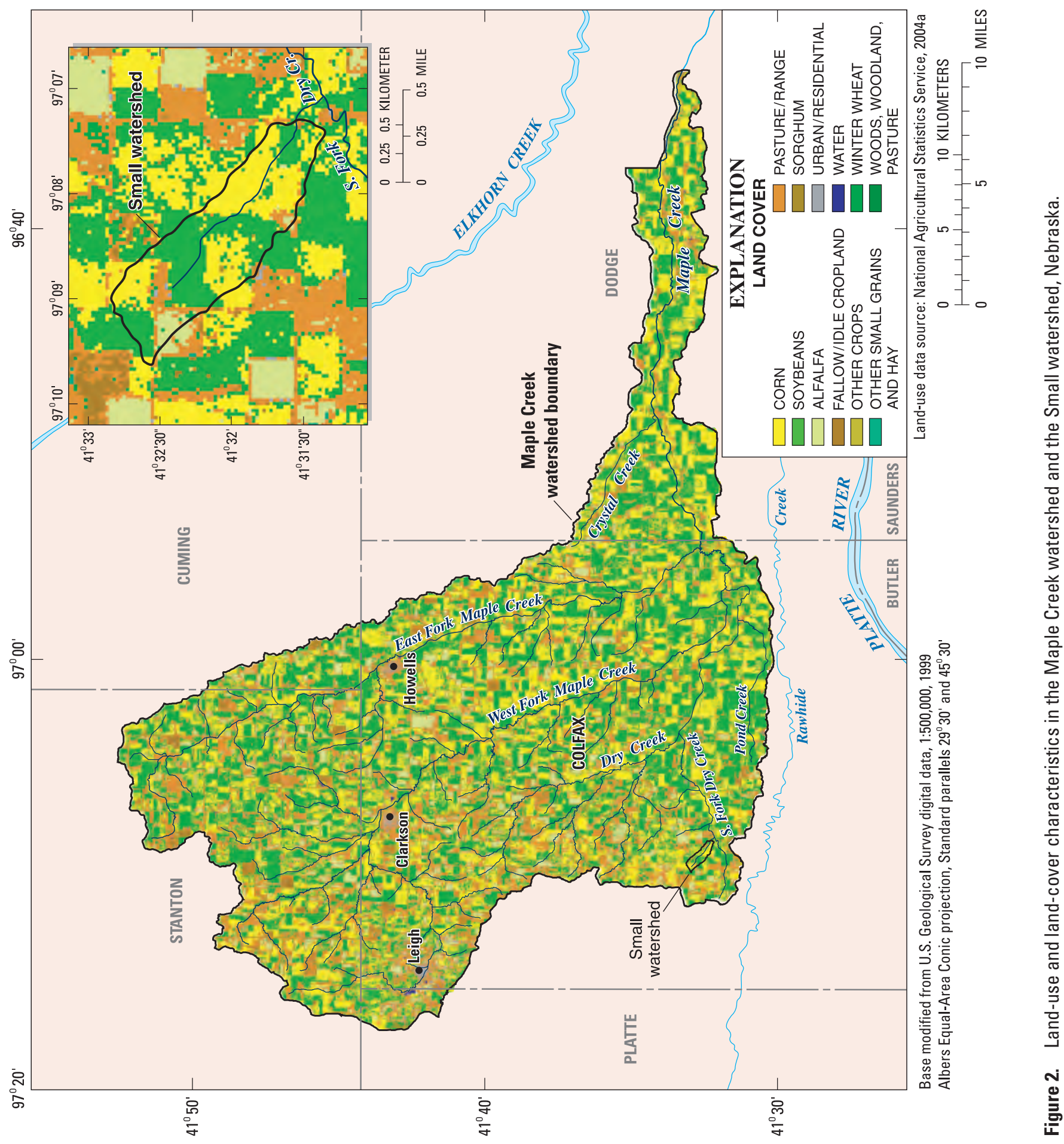


\section{Land Use, Population, and Cultural Features}

Maple Creek watershed drains parts of Cuming, Stanton, Platte, Colfax, and Dodge Counties in eastern Nebraska (fig. 2). This region was originally tall-grass prairie; however, most of the land was converted to agricultural uses after settlement (Huntzinger and Ellis, 1993). Agricultural practices dominate the study area that also includes some small rural communities and towns (Zelt, 1996). The agricultural and rural landscape that is prominent in the Maple Creek watershed is representative of the region and most of agricultural eastern Nebraska.

Land use in the Maple Creek watershed is predominantly cropland (fig. 2). In 2003, the principal crops of corn, soybeans, and alfalfa covered approximately 76 percent of the Maple Creek watershed (table 1) and 97 percent of the Small watershed. Pasture and other grassland covered about 18 percent of the study area, but only about 3 percent of the Small watershed.

Colfax County was used as a surrogate for temporal demographic trends for the Maple Creek watershed (fig. 3). Since 1900, the population in Colfax County has decreased by 770 and varied by approximately 2,500 people. The population of Colfax County in 2000 was approximately 10,400 (fig. 3). The towns in the watershed with the largest population are: Clarkson, Howells, and Leigh (fig. 4). These communities range in population from approximately 450 to 700 (U.S. Census Bureau, 2000). The population increase from 1990 to 2000 was 14.2 percent in Colfax County, 8.4 percent for Nebraska, and 13.0 percent nationwide (U.S. Census Bureau, 2000). Census block-level data for the year 2000 were used to display population density in the Maple Creek watershed (fig. 4).

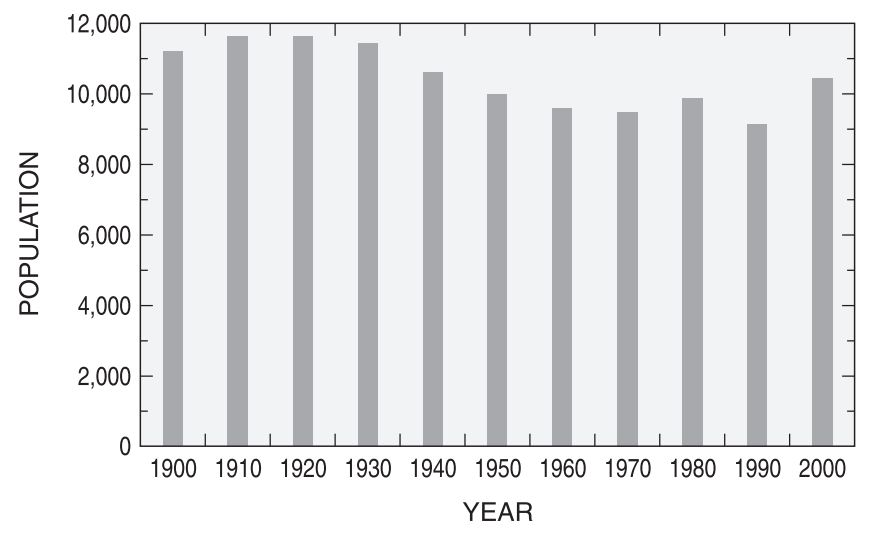

Figure 3. Population of Colfax County, Nebraska, 1900 to 2000 (U.S. Census Bureau, 2000).

\section{Agricultural Chemical Use}

Some common classifications of agricultural chemicals applied to enhance crop production are herbicides, insecticides, and fertilizers. Herbicides are applied to minimize or eradicate growth of unwanted plants and weeds that compete with crops for nutrients and water. Insecticides are applied to eradicate and (or) repel unwanted insects that consume the crops or otherwise inhibit optimal production. The availability of nutrients such as nitrogen, phosphorus, and potassium is necessary for crop growth and is commonly ensured by the application of fertilizers. Application of fertilizers, which commonly involves application and incorporation into the soil, provides crops with adequate quantities of nutrients that are sometimes not present in the soil in sufficient concentrations to sustain successful crop production.

Table 1. Land-use and land-cover characteristics of the Maple Creek watershed and the Small watershed, eastern Nebraska.

[Data from National Agricultural Statistics Service, 2004a; ha, hectare; CRP, enrolled in U.S. Department of Agriculture's Conservation Reserve Program; non ag, nonagricultural; --, area was less than 1 ha; Percentages may not sum to 100 because of rounding]

\begin{tabular}{|c|c|c|c|c|c|c|}
\hline \multirow[b]{2}{*}{ Land use/land cover } & \multicolumn{3}{|c|}{ Maple Creek watershed } & \multicolumn{3}{|c|}{ Small watershed } \\
\hline & $\begin{array}{l}\text { Area } \\
\text { (ha) }\end{array}$ & $\begin{array}{l}\text { Percentage of } \\
\text { agricultural land }\end{array}$ & $\begin{array}{l}\text { Percentage of total } \\
\text { watershed area }\end{array}$ & $\begin{array}{l}\text { Area } \\
\text { (ha) }\end{array}$ & $\begin{array}{l}\text { Percentage of } \\
\text { agricultural land }\end{array}$ & $\begin{array}{l}\text { Percentage of total } \\
\text { watershed area }\end{array}$ \\
\hline Corn & 28,770 & 37.5 & 30.1 & 69 & 48.6 & 47.3 \\
\hline Soybeans & 39,199 & 51.1 & 41.0 & 61 & 42.9 & 41.8 \\
\hline Pasture/range/CRP/non ag & 17,577 & -- & 18.4 & 4 & -- & 2.7 \\
\hline Alfalfa & 4,906 & 6.4 & 5.1 & 12 & 8.5 & 8.2 \\
\hline Fallow/idle cropland & 3,022 & 3.9 & 3.1 & -- & -- & -- \\
\hline Urban & 682 & -- & .7 & -- & -- & -- \\
\hline Woods, woodland pasture & 439 & -- & .4 & -- & -- & -- \\
\hline Winter wheat & 360 & .4 & .3 & -- & -- & -- \\
\hline Other small grains and hay & 329 & .4 & .3 & -- & -- & -- \\
\hline Sorghum & 111 & .1 & .1 & -- & -- & -- \\
\hline Water & 48 & -- & .05 & -- & -- & -- \\
\hline Other crops & 19 & .02 & .02 & -- & -- & -- \\
\hline
\end{tabular}




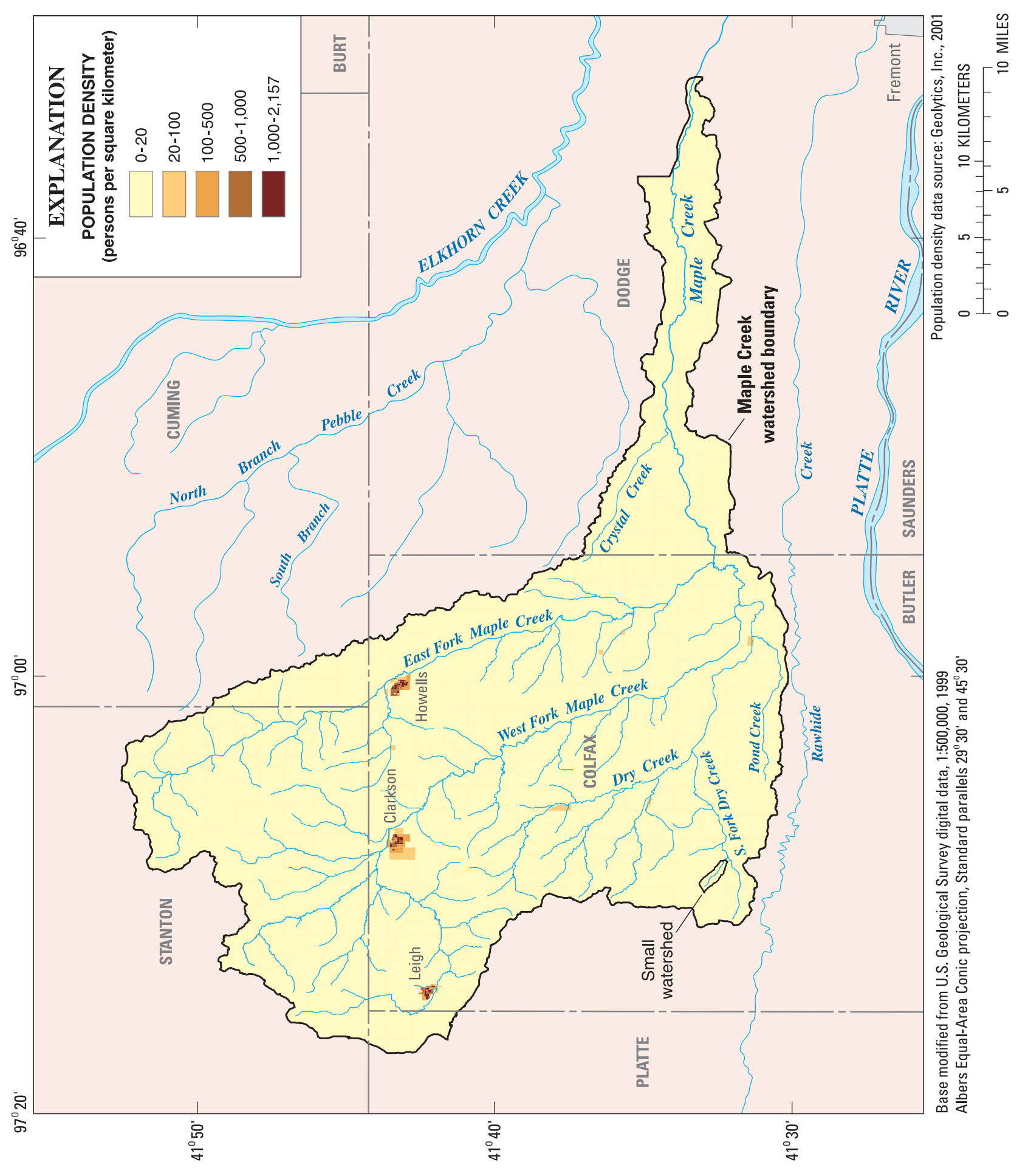

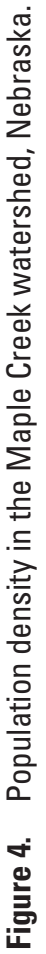


Estimates of agricultural chemical application rates were interpolated for Maple Creek watershed by applying statewide application rates to crop types and areas in the watershed. Information on application rates for the Small watershed was obtained through oral communication with the landowners. Agricultural chemicals that are commonly applied to corn and soybean crops in the Maple Creek watershed and the Small watershed include atrazine, glyphosate, trifluralin, nitrogen, and phosphorus (table 2). Within both the Maple Creek and Small watersheds, glyphosate was the most commonly applied herbicide, chlorpyrifos was the most commonly applied insecticide, and nitrogen was the most commonly applied fertilizer.

\section{Physiography and Topography}

Physiography refers to the physical features of the Earth's surface. The Maple Creek watershed lies entirely within the Dissected Till Plains Section of the Central Lowland Province, which is a part of the Interior Plains Division (Fenneman, 1946). Maple Creek flows generally southward and eastward through the glaciated region of eastern Nebraska, which is characterized by rolling hills and incised streams. Elevations in the Maple Creek watershed range from $541 \mathrm{~m}$ at the upper watershed boundary (Zelt, 1996), measured from North American Vertical Datum of 1988, to $361 \mathrm{~m}$ at the mouth of Maple Creek (fig. 5).

Table 2. Agricultural chemical application estimates for the Maple Creek watershed and the Small watershed, eastern Nebraska.

[Pesticide data for Maple Creek watershed from National Agricultural Statistics Service, 2003; fertilizer data for Maple Creek watershed from National Agricultural Statistics Service, 2004b; pesticide and fertilizer data for the Maple Creek watershed was interpolated from statewide figures based on crop type and area; pesticide and fertilizer data for Small watershed was obtained from oral communication with landowners (2004); ha, hectare; kg, kilogram; ua, data was unavailable; --, agricultural chemical not applied]

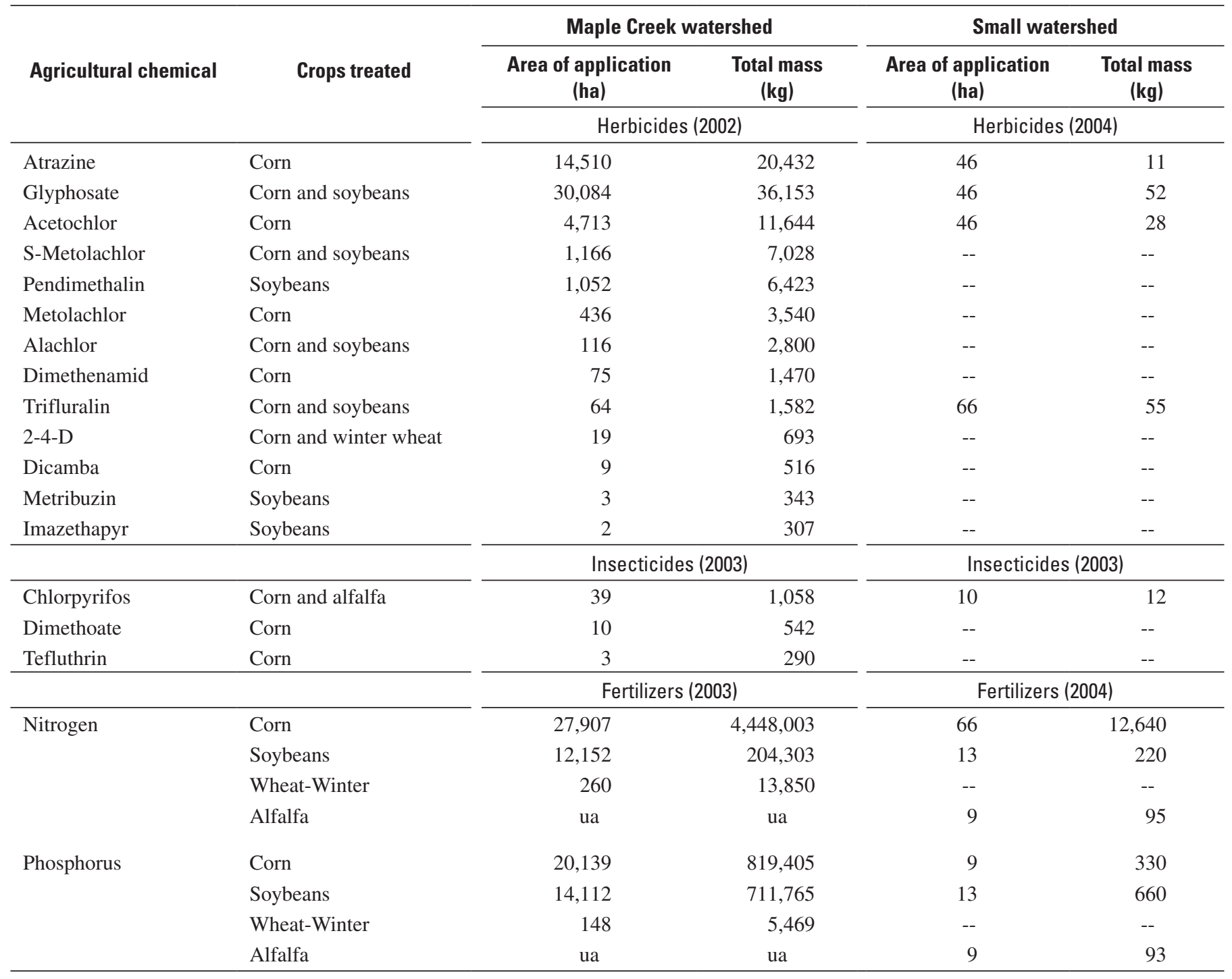




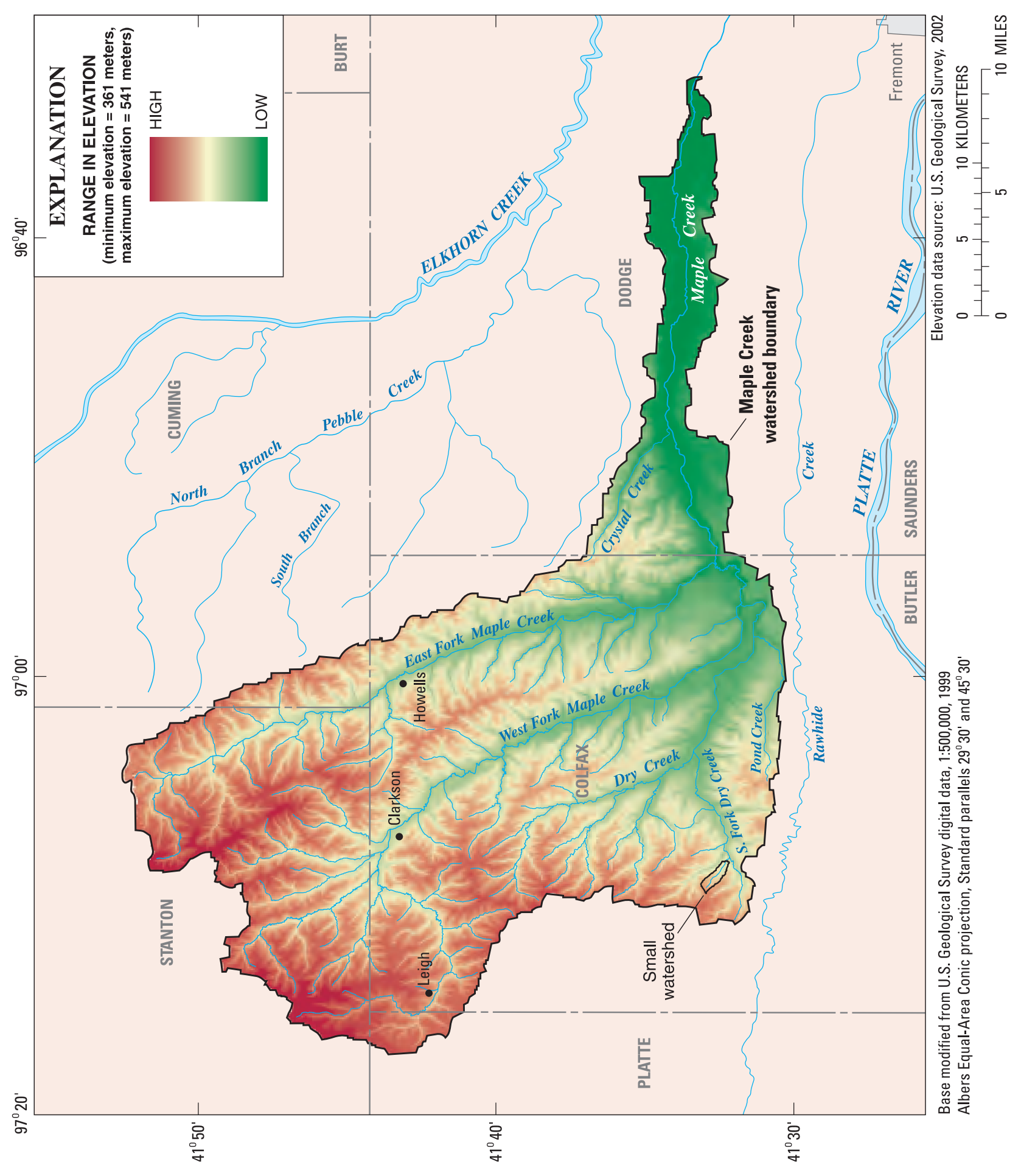

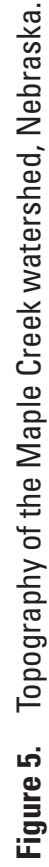


The Maple Creek watershed can be divided into two distinctly different topographic regions based on the relative relief and topographic diversity in these two areas (fig. 5). The upper and western part of the watershed is characterized by rolling hills of loess-mantled glacial till. The lower and eastern part of the watershed is mostly composed of the Maple Creek Valley and displays markedly less topographic relief than the upper part of the watershed.

The physiography and topography of the Small watershed are similar to the physiography and topography of the upper parts of the Maple Creek watershed. Elevations in the Small watershed range from approximately $500 \mathrm{~m}$ in the upper part of the watershed to approximately $450 \mathrm{~m}$, measured from North American Vertical Datum of 1988.

\section{Geology and Stratigraphy}

Loess, till, and alluvium are at the surface throughout the Maple Creek watershed. These Quaternary eolian, glacial, and fluvial deposits overlie bedrock geologic units of Cretaceousage sandstone, limestone, and shale (fig. 6). According to test-hole log information from Dodge County, bedrock is typically encountered approximately 9 to $83 \mathrm{~m}$ below land surface (University of Nebraska-Lincoln, Conservation and Survey Division, 1953). Loess, till, and alluvium are at the surface, and bedrock of Cretaceous age occurs at approximately 18 to $122 \mathrm{~m}$ below the surface in Colfax County (Bartlett and others, 1982). The sandstone and shale from the Dakota Formation are generally found underlying the eastern part of the watershed in Dodge County. Deposits of till in the area are composed primarily of fine-grained material and pockets of sand and gravelly sand (table 3 ). Till is the predominant material in the upland areas of the watershed. Deposits of till are either not present or occur as thin lenses in the valleys of the Platte River, lower Elkhorn River, and lower Maple Creek Valley.

\section{Soil}

Soil in the Maple Creek watershed is well suited for the cultivation of corn and soybeans. Parent material of the upland soil is eolian sand, silt, and loess, which results in mostly fine-grained soils throughout the watershed (fig. 7). The predominant soil types in the watershed were classified in the soil survey of Dodge County, Nebraska (Bartlett and Koepke, 1975), as Nora and Moody Series soils, which are deep, well to poorly drained, silty and silty clay soil. Although the soil is only classified for the upper $150 \mathrm{~cm}$ (centimeters), its thickness is known to extend to about 500 to $1,000 \mathrm{~cm}$ (Bartlett and others, 1982). In the upland areas of the Maple Creek watershed and in the Small watershed, the Nora-Crofton-Moody is the most prominent soil association (fig. 8) and covers 49 percent of the watershed. In the lower reaches of the Maple Creek valley and other alluvial areas of the watershed, the Zook-Shell-Hobbs soil association is most common (fig. 9). The grain-size distribution of this soil association is classified as fine. Additionally, in the lower reaches and alluvial areas of the watershed, loess-capped terrace deposits occur as remnant features from past lateral migration and degradation of the Maple Creek channel and its tributaries.

\section{Climate}

The climate of eastern Nebraska and Maple Creek is typical of a humid continental region that is characterized by hot summers and cold winters. There are several National Weather Service weather stations located in and around the Maple Creek watershed. In this report, the climate record from the Columbus, Nebraska, station was used (fig. 10). This station is part of the National Weather Service's Cooperative Station Network (station 251825) and has been in service since June 1948. Published data for minimum and maximum temperature and total daily rainfall at the Columbus station were obtained and monthly means were calculated (fig. 10). Mean values for temperature and precipitation for this station are based on 30-year normals for the period of record from 1971 through 2000 (National Climatic Center, 2005). At the Columbus station, mean annual precipitation was $723 \mathrm{~mm}$ (millimeters). Total annual precipitation in 2003 was $649 \mathrm{~mm}$, which was $74 \mathrm{~mm}$ less than the 30-year normal. Total annual precipitation in 2004 was $721 \mathrm{~mm}$, which was $2 \mathrm{~mm}$ less than the 30-year normal. Precipitation is typically greatest in May and June when convective thunderstorms produce intense, short-duration periods of rainfall (Huntzinger and Ellis, 1993). Mean monthly temperatures ranged from a maximum of $24.8^{\circ} \mathrm{C}$ (degrees Celsius) in July to a minimum of $-5.7^{\circ} \mathrm{C}$ in January (National Climate Center, 2005). The 30 -year mean annual temperature at the Columbus station is $10^{\circ} \mathrm{C}$.

Evapotranspiration is an important component of the hydrologic cycle, especially in agricultural areas where crop production is dependent on soil moisture content and the availability of water to plants. Zelt (1996) reported that the mean annual free-water-surface evapotranspiration, for 1956 to 1970 , was about $1,100 \mathrm{~mm}$, while Dugan and Zelt (2000) indicated that from 1951 through 1980, mean annual potential evapotranspiration was about $1,050 \mathrm{~mm}$ and mean annual actual evapotranspiration was about $500 \mathrm{~mm}$.

\section{Hydrology}

Surface- and ground-water hydrology are important components of the hydrologic cycle and the environmental setting of a watershed. The quality and quantity of these resources can reflect how land-use practices are implemented, distributed, and how they function throughout the watershed. In agricultural and residential settings, irrigation practices cycle ground water to the surface, which makes moisture available to crops and other plants. This process in agricultural settings can lower ground-water levels, increase surfacewater flow in streams, and make more moisture available for evaporation. Although ground-water levels are not usually lowered at a local scale because of residential irrigation, more water is introduced to surface drainage and there is the potential for increased evaporation. 


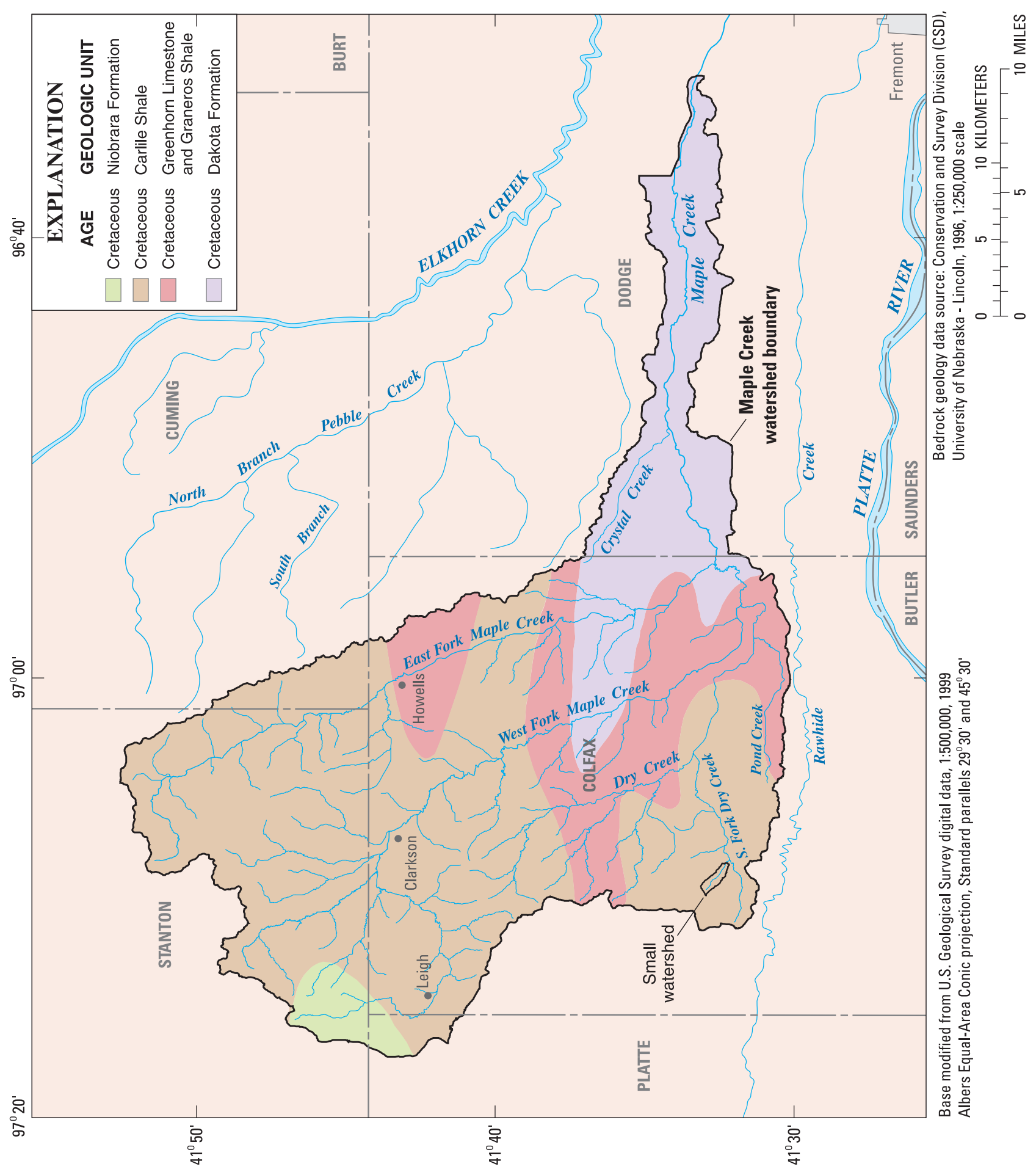

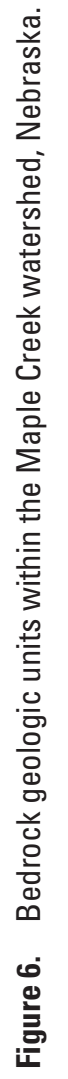


Table 3. Stratigraphy and hydrogeology of Maple Creek watershed, eastern Nebraska.

[Geologic characteristics and descriptions modified from Flowerday and others, 1998, and Miller and Appel, 1997]

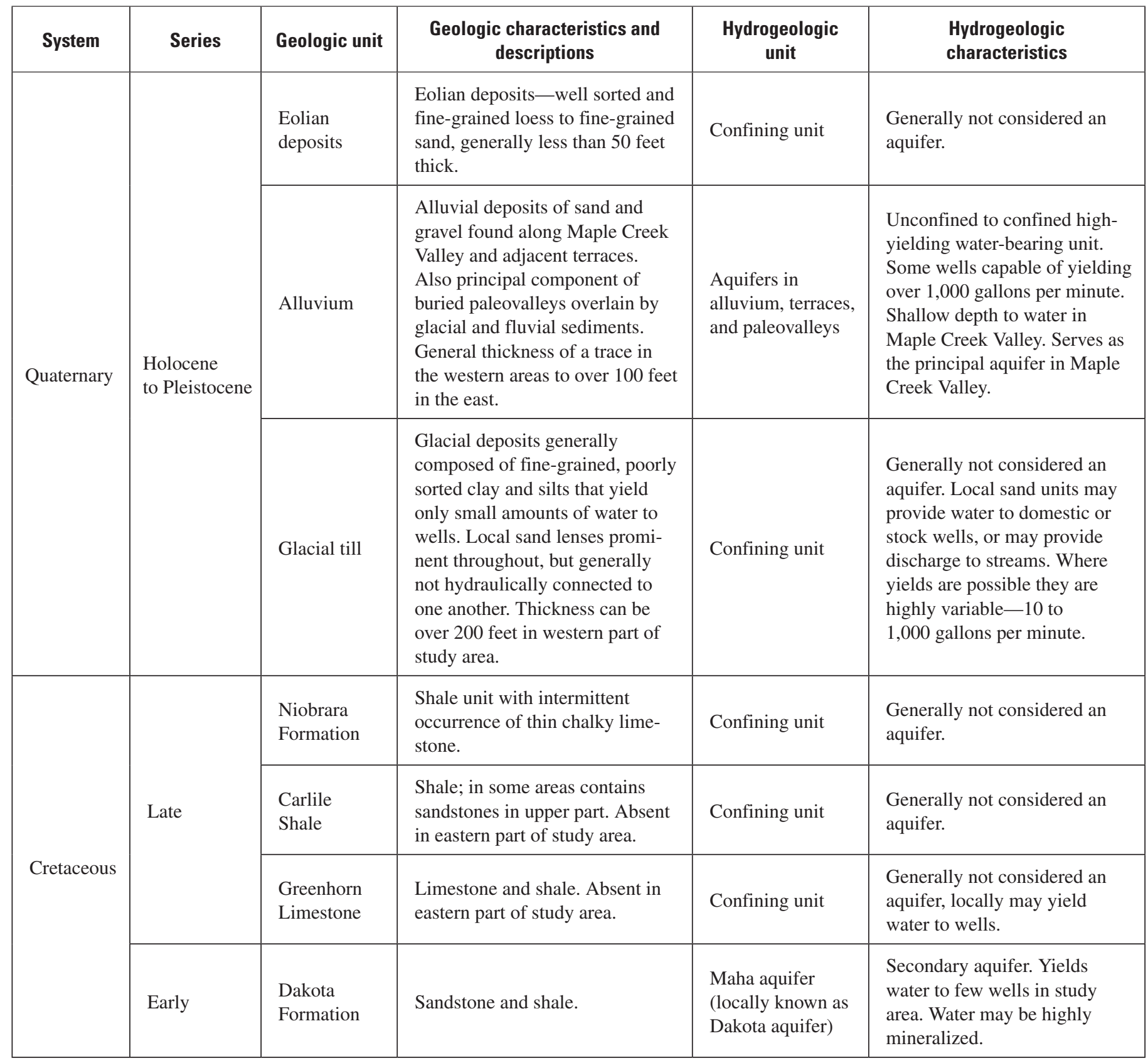




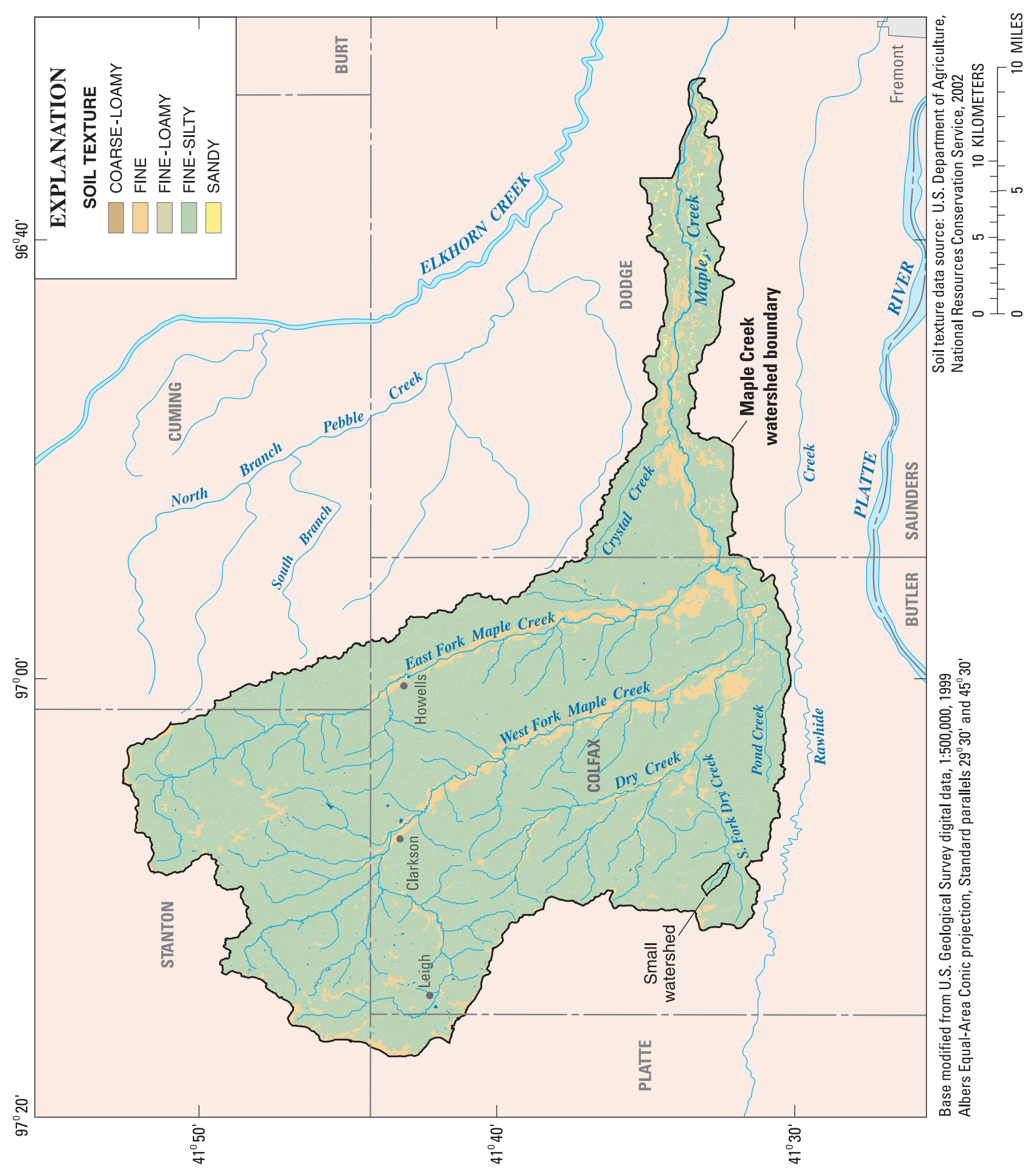

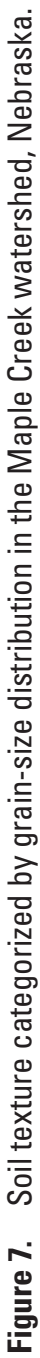




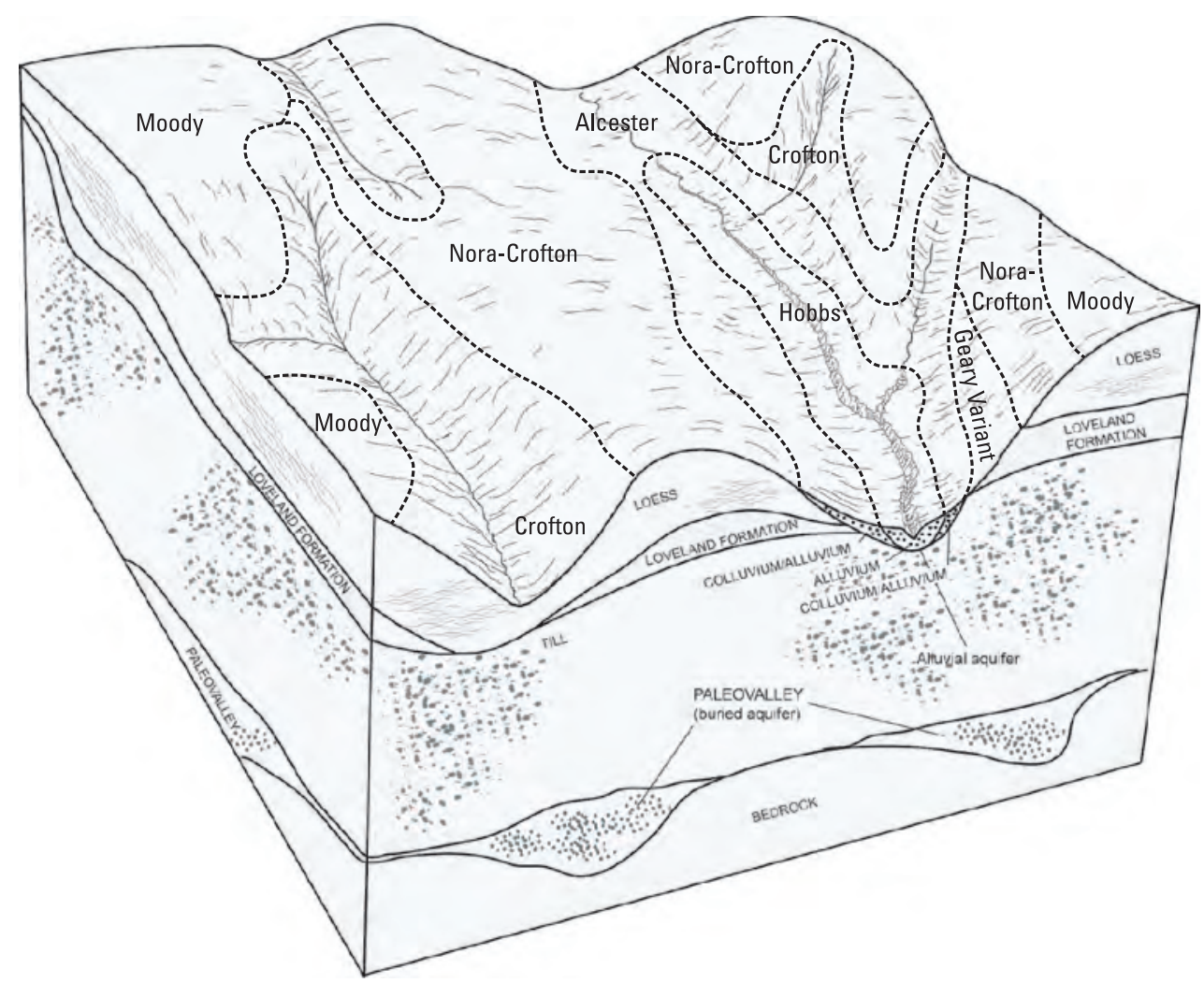

Figure 8. Generalized block diagram of the Nora-Crofton-Moody soil association and underlying lithology that is typical of upland areas of the Maple Creek watershed, Nebraska (modified from Bartlett and Koepke, 1975).

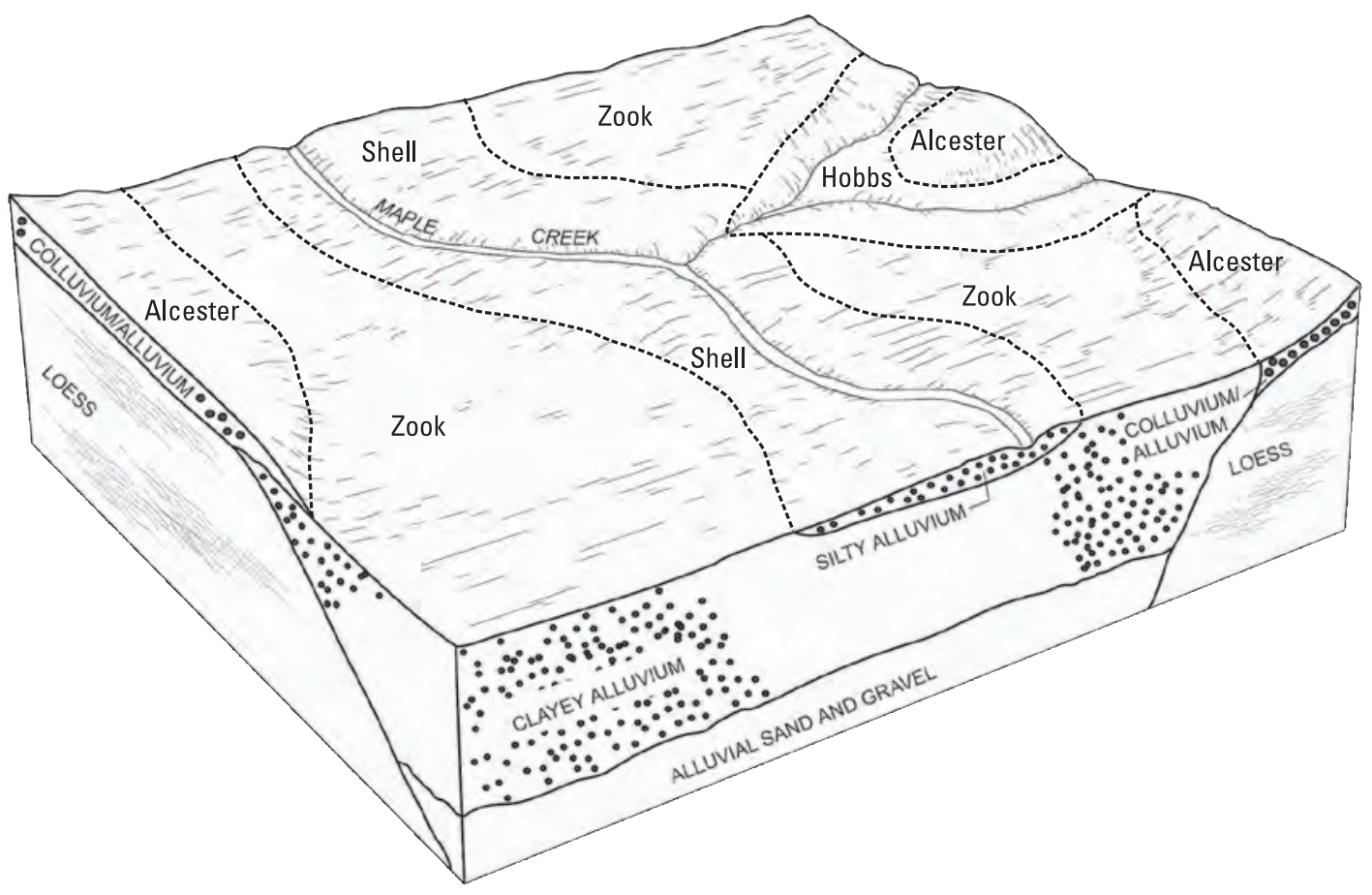

Figure 9. Generalized block diagram of the Zook-Shell-Hobbs soil association and underlying lithology that is typical of lowland areas of the Maple Creek watershed, Nebraska (modified from Bartlett and Koepke, 1975). 


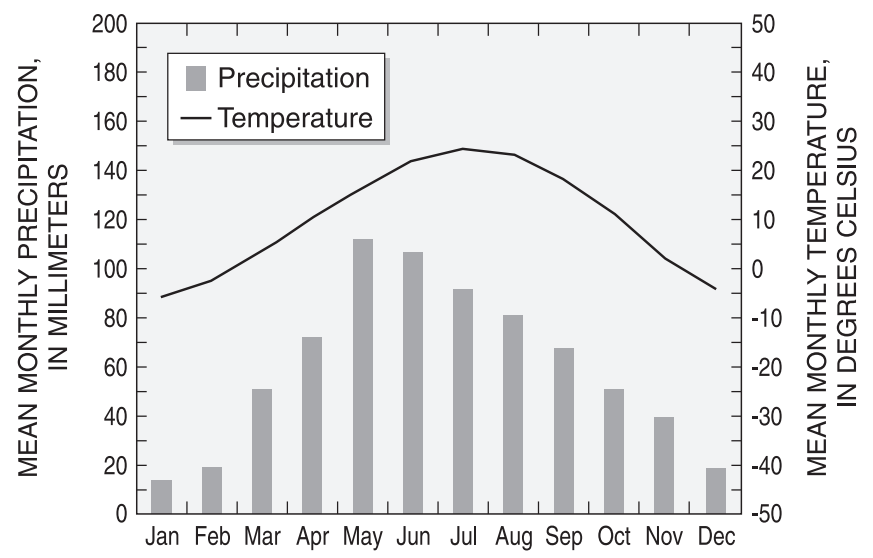

Figure 10. Mean monthly precipitation and temperature for Columbus, Nebraska, 1971-2000 (National Climatic Center, 2005).

\section{Streams and Streamflow Characteristics}

The surface-water drainage network for the Maple Creek watershed consists of the main stem of Maple Creek and three major, named tributaries-East Fork of Maple Creek, West Fork of Maple Creek, and Dry Creek (fig. 11). All of these tributaries generally flow to the southeast to their mouths at Maple Creek. Maple Creek (Hydrologic Unit Code 10220003) flows into the Elkhorn River, which then flows into the Platte River (fig. 1). The Maple Creek watershed is approximately $955 \mathrm{~km}^{2}$. Much of the drainage network is incised, resembling a narrow, meandering ditch in tributary channels with stream banks up to $5 \mathrm{~m}$ high enclosing a 20-m wide main channel near the mouth. Springs are common along stream channels throughout the basin, flowing primarily during the early- to mid-growing season in tributary channels and perennially in main channel reaches. Named stream channels upstream from the major confluences may have perennial flow. Flow in small tributaries, however, is often intermittent and relies on the saturation deficit of the contributing slopes. Field observations and measurements at the Small watershed indicate flows are minimal until after late spring precipitation. During 2003 and 2004, flow in the Small watershed tributary was continual for a period of about 2 months and ephemeral otherwise.

Precipitation is the primary source of water for maintaining soil moisture and recharging shallow ground water in the basin. Depending on antecedent conditions, most rainfall that reaches the surface is either evaporated or transported to the streams as overland flow. The remainder infiltrates to the soil and some recharges ground water. Overland flow is more probable during periods of frequent rainfall events, because soil moisture levels are maintained by infiltration of precipitation and stream discharge is increased by ground-water influx. Contributions to streamflow also include drainage from hydraulically connected sand units that become saturated at different rates than surrounding material and also drain water to the streams at differing rates. Soil moisture levels may decrease as precipitation becomes less frequent in late summer. This results in ephemeral streamflow, and ground water becomes the best available source of water for agricultural use. This secondary source of water is supplied by irrigation wells and is often needed during these dry periods to maintain soil moisture levels, recharge shallow ground water, and sustain crop growth.

If sufficient ground water is available and installation of an irrigation well is feasible, irrigation provides a reliable supplemental source of water. Irrigated areas of the watershed can be defined generally by the presence of wells that were drilled into a deep, regional aquifer for the sole purpose of providing irrigation water. Irrigation water and precipitation collectively provide recharge to aquifers and maintain baseflow conditions in streams.

The USGS has operated a stream gage at Maple Creek near Nickerson (USGS Station 06800000) since 1952 (fig. 11). On July 23, 1991, this station was moved approximately $3.2 \mathrm{~km}$ (kilometers) upstream from its original location. This gage has a period of record for discharge from water year 1952 to the present (fig. 12; table 4). The mean annual discharge of Maple Creek is $2.27 \mathrm{~m}^{3} / \mathrm{s}$ (cubic meters per second) for water years 1952 through 2004. The lowest daily mean discharge for water years 1952-2004 was $0.0028 \mathrm{~m}^{3} / \mathrm{s}$, recorded on January 15,1956 . The highest daily mean discharge for water years 1952-2004 was a discharge of $295 \mathrm{~m}^{3} / \mathrm{s}$, recorded on August 6, 1996 (Hitch and others, 2005). Table 4 also allows comparison of drainage area and stream flow characteristics of the stream gage at Maple Creek near Nickerson to other stream gages in the Elkhorn River Basin. General rainfall-runoff relations in Maple Creek are represented by the magnitude and timing of precipitation events and their temporal relation to discharge at the Maple Creek near Nickerson gage (fig. 13). From October 1997 through October 1998, the response time between peak rainfall amounts recorded at Columbus and peak discharge at the Maple Creek near Nickerson stream gage was approximately 24 hours.

As part of the ACT study, a stream-gaging station was established at the mouth of the Small watershed. This seasonal gage (USGS station 06799750) was in Colfax County, approximately $13 \mathrm{~km}$ northwest of Schuyler, Nebraska (fig. 11). The drainage area of the Small watershed is approximately $1.5 \mathrm{~km}^{2}$, and its land use is approximately 97 percent cropland. The period of record for this site was intermittent from June 2003 through December 2004. Stage measurements were measured using a triple-orifice bubbler (MetOne Instruments, Inc., Grants Pass, Oregon). Depending on flow rate, discharge was determined from one of two ways. For flows between 0 and $0.04 \mathrm{~m}^{3} / \mathrm{s}$, the Cone Equation and a conversion factor was used to calculate discharge based on depth (hydraulic head) of water over the 90-degree V-notch weir (Bureau of Reclamation, 2001; eq. 1).

$$
Q=\left(2.49 h_{1}^{2.48}\right) \times 0.02832,
$$

where $Q \quad=\begin{aligned} & \text { discharge over weir, in meters per second; } \\ & \text { and }\end{aligned}$ 


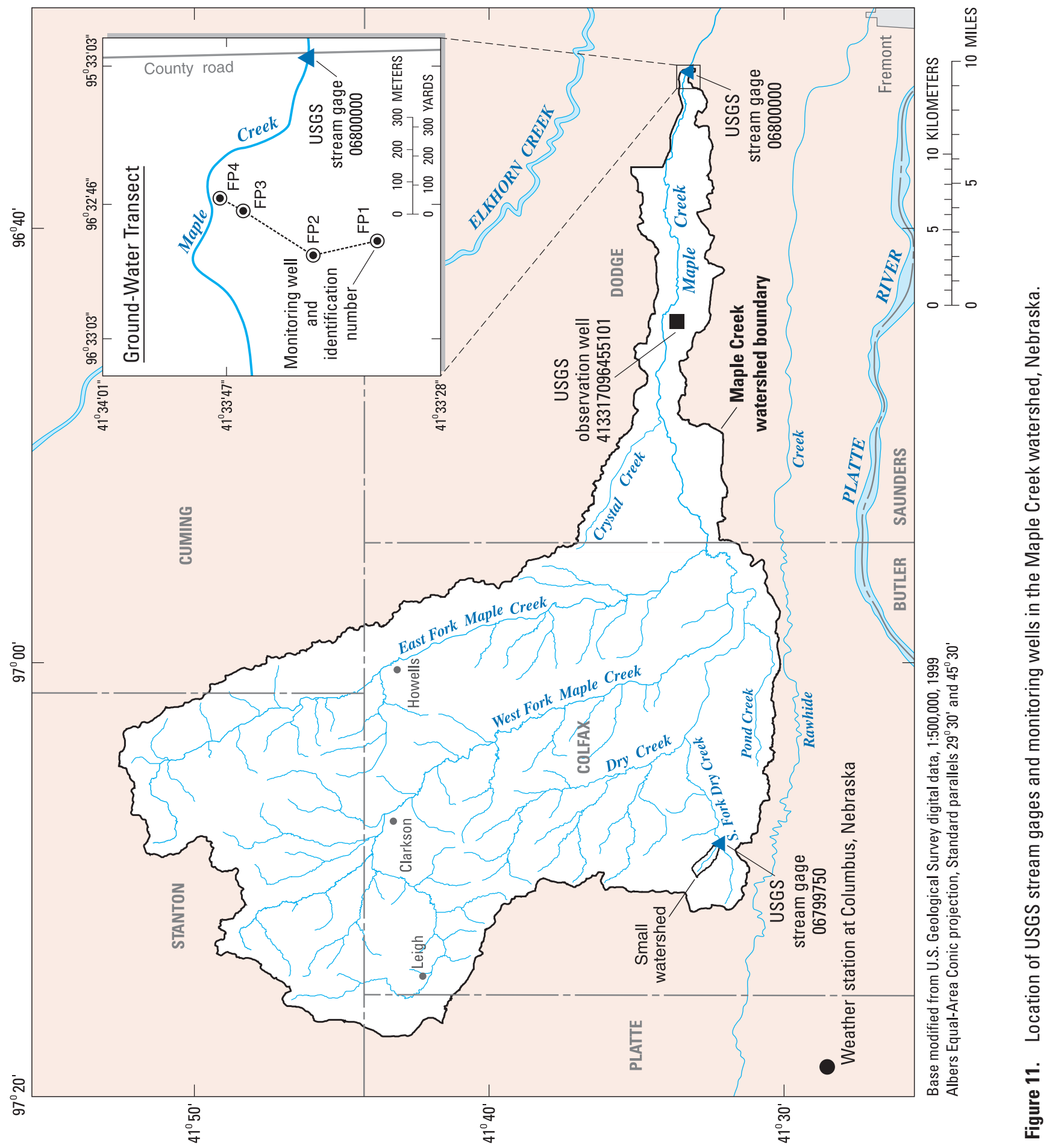




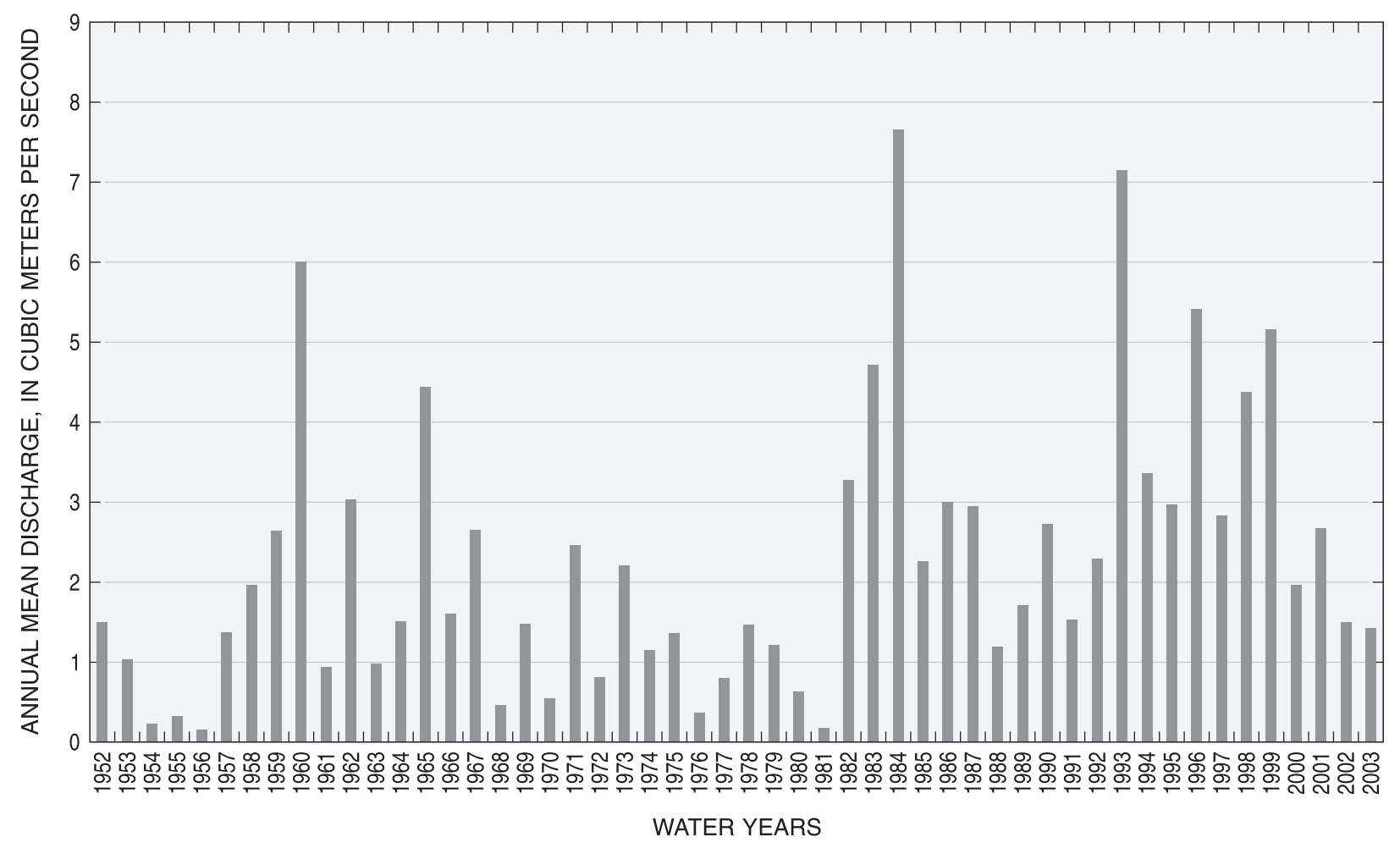

Figure 12. Annual mean discharge for Maple Creek near Nickerson, Nebraska, water years 1952 to 2003.

Table 4. Statistical summary of streamflow at selected sites in the Elkhorn River Basin, Nebraska (Hitch and others, 2005).

[USGS, U.S. Geological Survey; $\mathrm{km}^{2}$, square kilometers; $\mathrm{m}^{3} / \mathrm{s}$, discharge in cubic meters per second]

\begin{tabular}{|c|c|c|c|c|c|c|}
\hline \multirow[b]{2}{*}{$\begin{array}{l}\text { USGS } \\
\text { station } \\
\text { number }\end{array}$} & \multirow[b]{2}{*}{ USGS station name } & \multirow[b]{2}{*}{$\begin{array}{c}\text { Drainage } \\
\text { area } \\
\left(\mathbf{k m}^{2}\right)\end{array}$} & \multicolumn{4}{|c|}{ Summary statistics } \\
\hline & & & $\begin{array}{l}\text { Water } \\
\text { years }\end{array}$ & $\begin{array}{l}\text { Mean annual } \\
\qquad\left(\mathrm{m}^{3} / \mathrm{s}\right)\end{array}$ & $\begin{array}{c}\text { Highest } \\
\text { daily mean } \\
\left(\mathrm{m}^{3} / \mathrm{s}\right)\end{array}$ & $\begin{array}{l}\text { Lowest } \\
\text { daily mean } \\
\left(\mathrm{m}^{3} / \mathrm{s}\right)\end{array}$ \\
\hline 06800000 & Maple Creek near Nickerson, Nebr. & 955 & 1952-2004 & 2.27 & 295 & 0.0028 \\
\hline 06799445 & Logan Creek at Wakefield, Nebr. & 1,406 & 2003-2004 & 3.96 & 131 & 1.25 \\
\hline 06799100 & North Fork Elkhorn River near Pierce, Nebr. & 1,815 & 1960-2004 & 2.95 & 295 & 0.076 \\
\hline 06799460 & Logan Creek near Bancroft, Nebr. & 2,211 & 2003-2004 & 6.54 & 157 & 1.59 \\
\hline 06799500 & Logan Creek near Uehling, Nebr. & 2,628 & 1942-2004 & 6.63 & 569 & 0.173 \\
\hline 06797500 & Elkhorn River at Ewing, Nebr. & 3,626 & 1947-2004 & 5.47 & 240 & 0.127 \\
\hline 06799000 & Elkhorn River at Norfolk, Nebr. & 7,226 & 1946-2004 & 15.2 & 496 & 0.935 \\
\hline 06799315 & Elkhorn River at Pilger, Nebr. & 11,292 & 2001-2004 & 15.7 & 250 & 2.89 \\
\hline 06799350 & Elkhorn River at West Point, Nebr. & 12,121 & 1973-2004 & 28.5 & 736 & 1.16 \\
\hline 06800500 & Elkhorn River at Waterloo, Nebr. & 17,871 & 1929-2004 & 38.5 & 2,660 & 1.81 \\
\hline
\end{tabular}




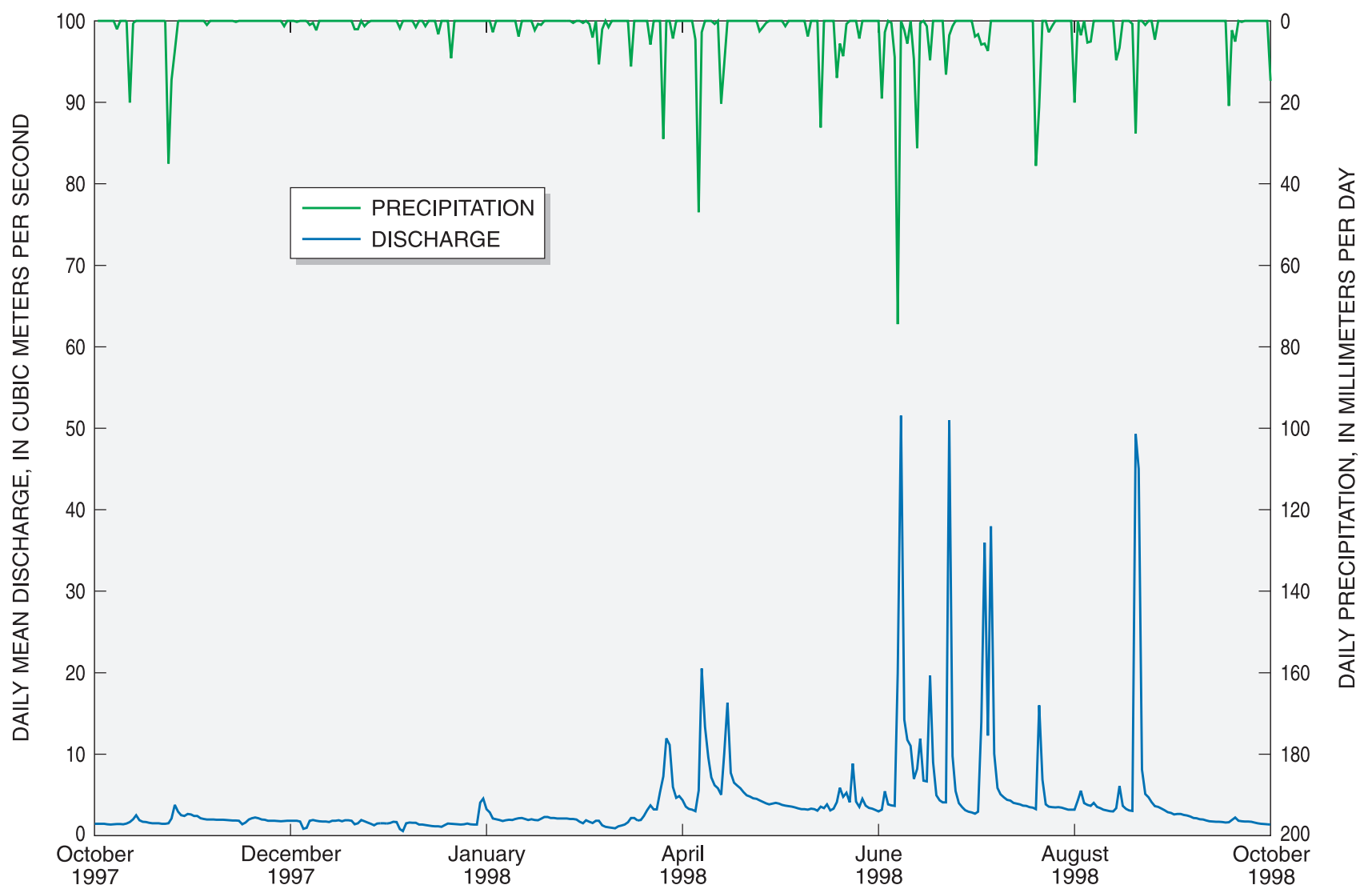

Figure 13. Daily precipitation at Columbus and discharge at Maple Creek near Nickerson, Nebraska, October 1997 to October 1998.

$h_{1} \quad=$ hydraulic head on the weir, in feet.

When the flow rate was greater than $0.04 \mathrm{~m}^{3} / \mathrm{s}$, a conversion table created with the Culvert Analysis Program (Fulford, 1998) for the $1.98 \mathrm{~m}$ corrugated culvert was used to convert head in the culvert to discharge. Instantaneous discharge at the stream gage in the Small watershed ranged from 0 to $1.62 \mathrm{~m}^{3} / \mathrm{s}$ during the operational periods. Precipitation was also measured in the Small watershed using a factory calibrated $15.25-\mathrm{cm}$ diameter tipping bucket rain gage. General rainfall-runoff relations for the Small watershed are shown by the magnitude and timing of local precipitation events in relation to discharge at the stream gage (fig. 14). The response time between peak rainfall intensity and peak discharge in the Small watershed was observed to be 2 to 6 hours.

\section{Major and Minor Aquifers}

Maple Creek watershed is underlain by the High Plains and the Maha (Dakota) aquifer systems (table 5). In the western part of the watershed, some wells obtain water from Quaternary deposits of the High Plains aquifer system. In the glaciated regions of eastern Nebraska, Pliocene-Pleistocene deposits are sources of ground water for irrigation wells. These deposits are associated with buried pre-glacial channels that are up to $8 \mathrm{~km}$ wide and $60 \mathrm{~m}$ deep. These channel-fill deposits are composed of silt and clay with some intermittent sand and gravel lenses and are similar to pre-glacial channels found in southeast Nebraska (Tanner and Steele, 1991). In areas where these sources are not available, perched or semi-perched ground water is used as an intermittent source of water for irrigation (Flowerday and others, 1998).

Ground-water influx constitutes the majority of streamflow during the late growing season and through the winter. This contribution occurs where stream channels intersect with unconsolidated material and unconfined sand, gravel, and perched aquifers above the Dakota Formation, which is found in the eastern part of the watershed (table 5). Water levels in wells adjacent to the Maple Creek main stem in Dodge County range from 1 to $25 \mathrm{~m}$ below land surface (U.S. Geological Survey, 2005). Discrete water-level measurements were recorded bi-annually from 1968 to 2004 at a 41-m deep well in Dodge County (USGS 413317096455101) (fig. 11). Water-levels over this period of record fluctuated from approximately 21 to $24 \mathrm{~m}$ below land surface (fig. 15). In the western part of the study area, the sub-surface matrix is composed chiefly of glacial tills, in which the water-levels are commonly $60 \mathrm{~m}$ below the land surface where ground water is present (Flowerday and 


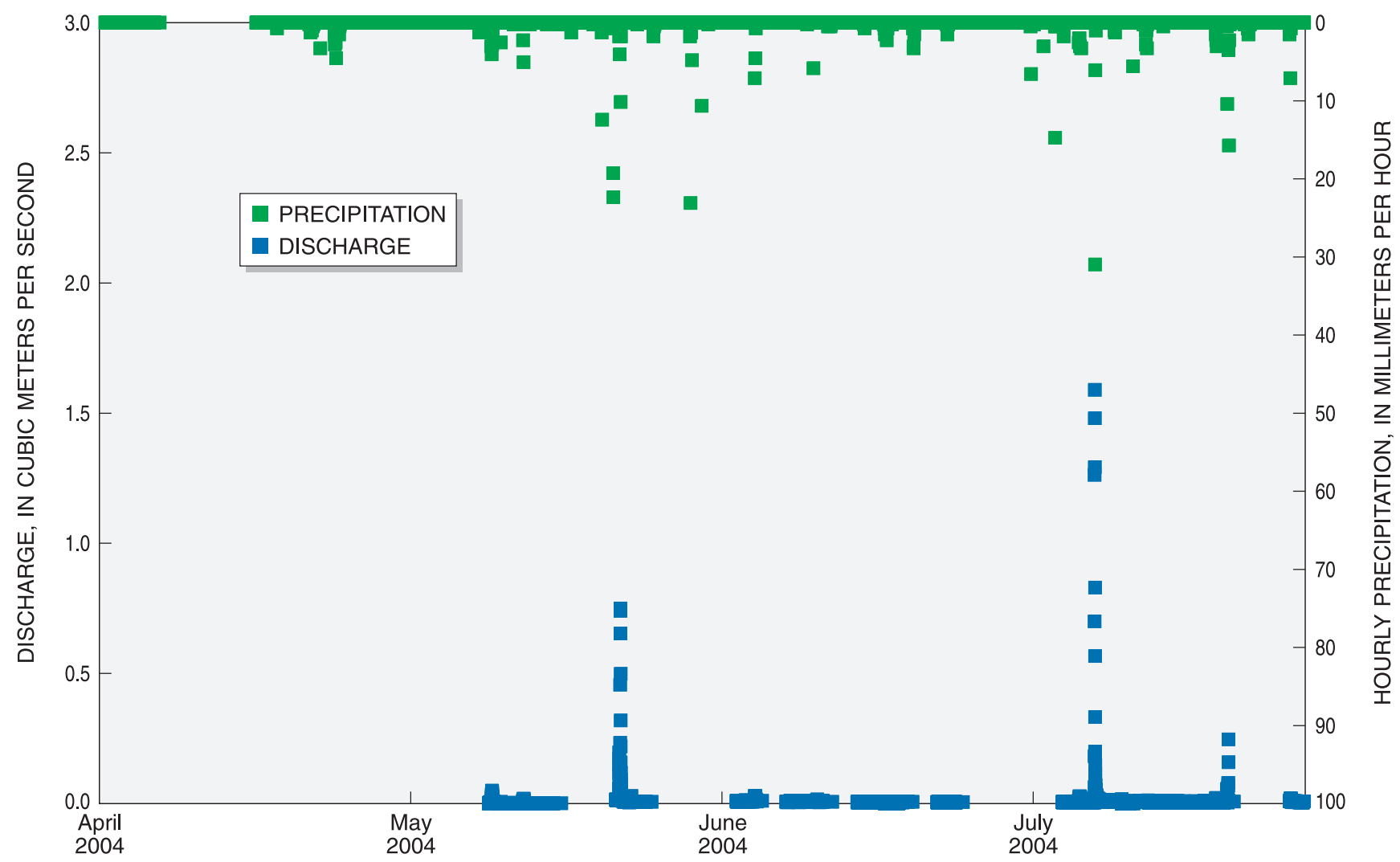

Figure 14. Hourly precipitation at the Small watershed and discharge at the Small watershed stream gage (06799750), April to July 2004.

Table 5. Major features of aquifer settings in Maple Creek Valley, eastern Nebraska.

[Modified from Miller and Appel, 1997; and Flowerday and others, 1998]

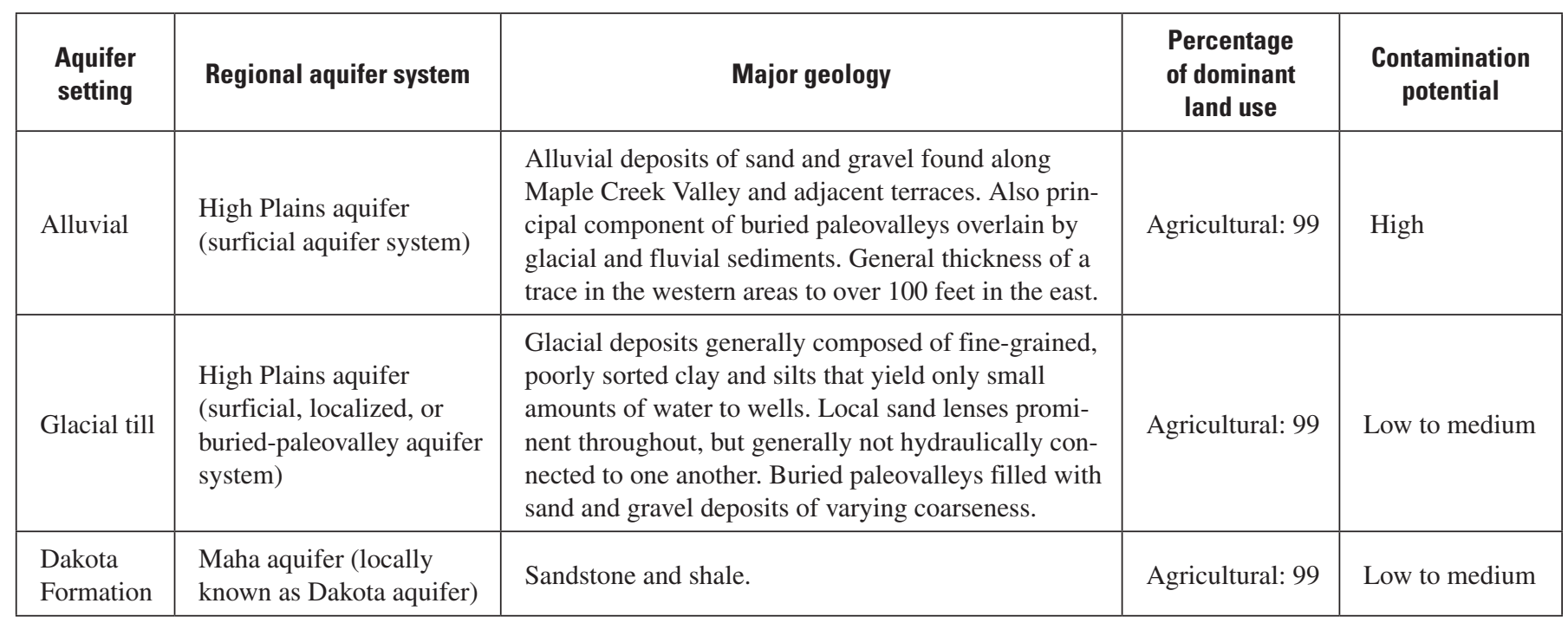




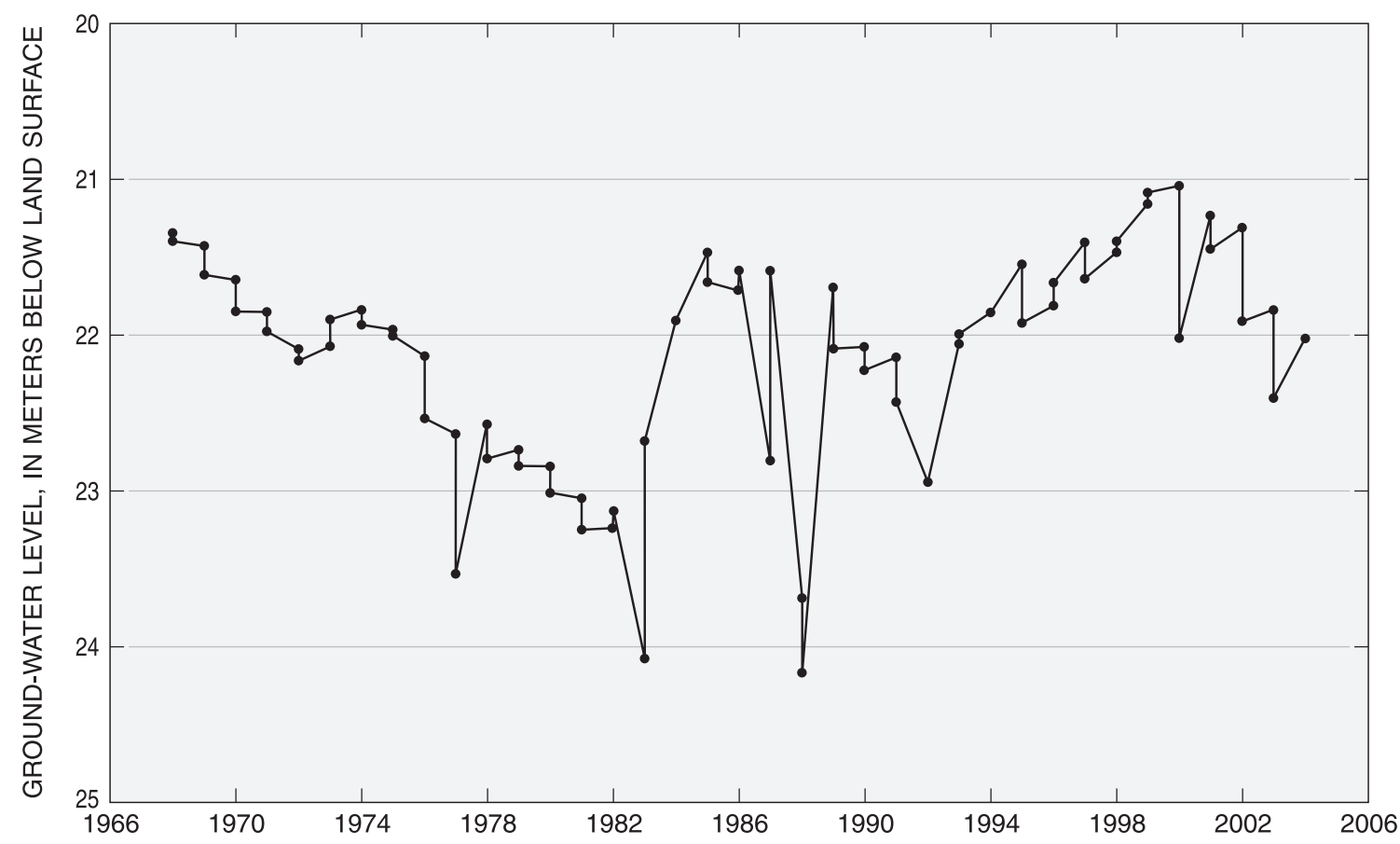

Figure 15. Discrete ground-water level measurements for USGS well 413317096455101, June 1968 through April 2004.

others, 1998). Regional groundwater flow is from the northwest to the southeast (Flowerday and others, 1998).

As part of the ACT study, monitoring wells were installed at four sites along a 500-m transect adjacent to Maple Creek to monitor ground-water quality and the direction of groundwater flow from south of Maple Creek. The wells were installed using USGS protocols (Lapham and others, 1997). The first site of the transect is in a corn field (site FP-1), the second site is adjacent to the corn field (site FP-2), the third site is located in a pasture (site FP-3), and the fourth site (site FP-4) is in a riparian area adjacent to Maple Creek (fig. 11). At each of the four sites, three wells were installed; shallow, intermediate, and deep. The depth of the shallow well at each site was set $1.5 \mathrm{~m}$ below the water-table level at the time of installation. The depths of the subsequent wells were set at approximate $3.5-\mathrm{m}$ intervals below the shallowest well at each site. Water levels in these wells fluctuated throughout the growing season with higher levels in May and June and lower levels in July and August (fig. 16; Hitch and others, 2005).

\section{Modifications of the Natural Hydrology}

The majority of lakes and ponds found in the Maple Creek watershed are not naturally occurring but are the result of impoundments (Huntzinger and Ellis, 1993). These lakes and ponds can attenuate flood peaks and act as sinks for contaminants that are associated with sediment in surface runoff. Most ponds are poorly lined and tend to leak, which creates points of recharge to the ground water that would otherwise be bypassed by overland flow. Ponds also are sources of surface water that are used commonly for watering livestock or occasionally for other uses.

In June 1944, peak discharge at the original Maple Creek gage (U.S. Highway 77) was indirectly measured at $991 \mathrm{~m}^{3} / \mathrm{s}$, exceeding the 500-year recurrence interval calculated by Soenksen and others (1999). In response to this event, reaches of Maple Creek were straightened for the purpose of flood control (Rus and others, 2003). Approximately $30 \mathrm{~km}$ of the main stem of Maple Creek was straightened, from the stream gage location upstream to the mouth of East Fork of Maple Creek. Other sections of Dry Creek (approximately $10 \mathrm{~km}$ ), West Fork of Maple Creek (approximately $5 \mathrm{~km}$ ), and the East Fork of Maple Creek (approximately $20 \mathrm{~km}$ ) also were straightened for flood control.

The practice of stream-channel straightening also is employed in agricultural areas to slow or reduce lateral channel migration to subsequently reduce the loss of cropland. Straightening removes natural features associated with stream channels such as meanders, pools, and riffles that decrease flow velocities and dissipate energy. Straightened channels provide a more direct conveyance for surface-water runoff than drainage networks that have developed naturally. Consequently, chemicals applied to the land surface could be transported through a watershed with straightened channels 

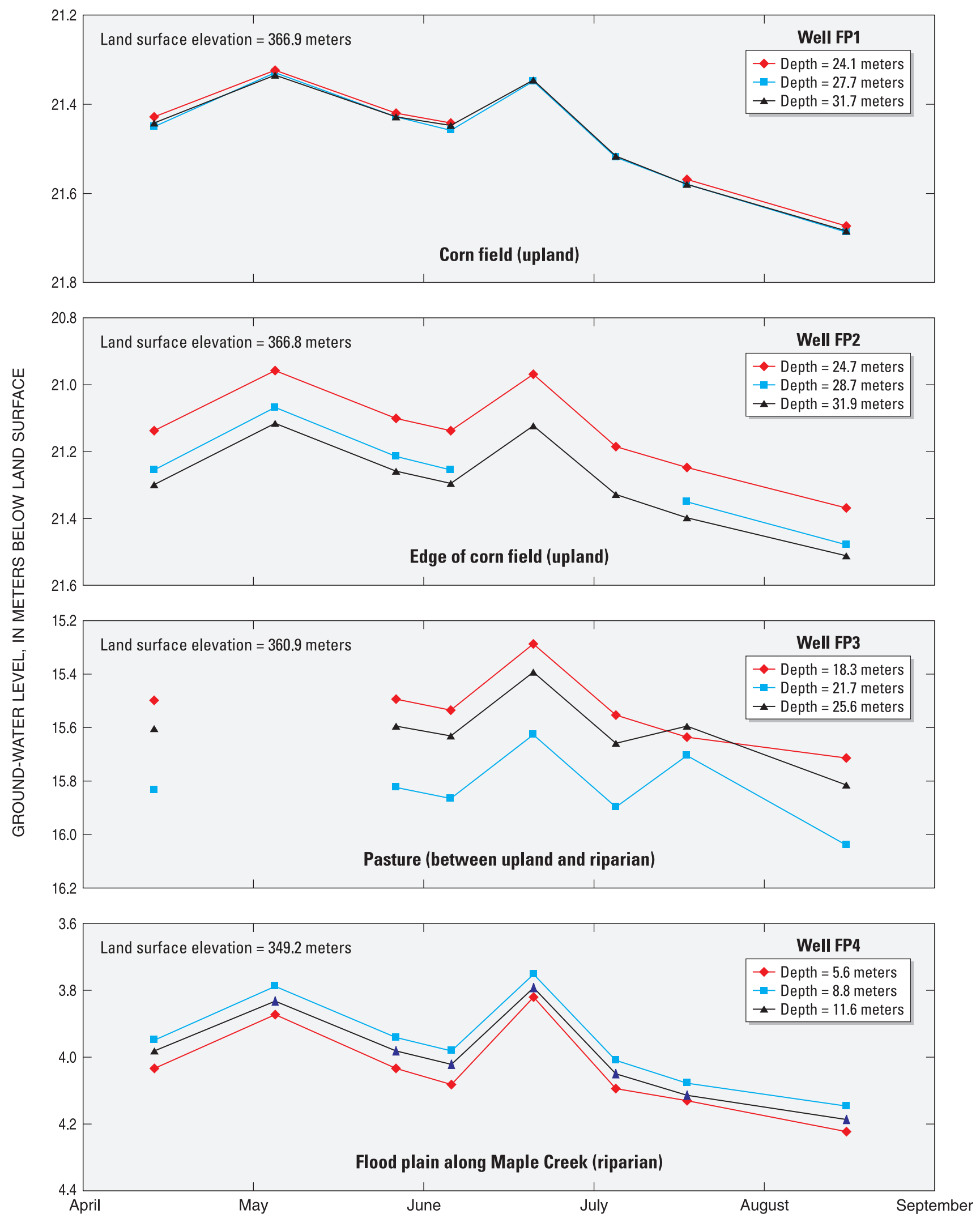

Figure 16. Water levels in wells in the ground-water transect study area near Nickerson, Nebraska, 2004. 
faster than in a watershed with a naturally developed drainage network.

\section{Summary}

This report describes the environmental setting of the Maple Creek watershed and a Small watershed located within the drainage area of Maple Creek in the context of how agricultural practices, which include agricultural chemical applications and irrigation practices, interface with natural settings and hydrologic processes. The Maple Creek watershed covers 955 square kilometers in eastern Nebraska, and is dominated by agricultural land use. The Small watershed is approximately 1.5 square kilometers and is used almost exclusively for agricultural crop production. The Maple Creek watershed is one of seven study areas currently included in a nationwide study of the sources, transport, and fate of water and agricultural chemicals in a diverse set of agricultural watersheds. The Maple Creek watershed was selected for this study because its watershed represents the agricultural setting that characterizes eastern Nebraska. The information included in this report is intended to be a reference for the comparison of agricultural settings examined by this study and in other watersheds across the Nation.

Activities related to agricultural land use commonly involve the application of agricultural chemicals to inhibit or enhance natural processes that aid in successful crop production. The use of agricultural chemicals in both the Maple Creek watershed and the Small watershed includes herbicides, insecticides, and fertilizers. Application rates of agricultural chemicals in both watersheds were summarized, and it was determined that glyphosate and atrazine were the most commonly applied herbicides, chlorpyrifos was the most commonly applied insecticide, and the use of nitrogen was the most prevalent fertilizer application.

\section{References Cited}

Baker, Maurice, Peterson, Nancy, and Kamble, Shripat, 1990, Pesticide use on crops in Nebraska-1987: Agricultural Research Division, Institute of Agricultural and Natural Resources, University of Nebraska Research Bulletin 311, August 1990, 34 p.

Bartlett, P.A., and Koepke, B.E., 1975, Soil survey of Dodge County, Nebraska: U.S. Department of Agriculture, Soil Conservation Service, and University of Nebraska, $11 \mathrm{p}$.

Bartlett P.A., Saeger, W.H., and Huso, S.K., 1982, Soil survey of Colfax County, Nebraska: U.S. Department of Agriculture and University of Nebraska, $151 \mathrm{p}$.

Bureau of Reclamation, 2001, Weirs, chap. 7 of Water measurement manual - a guide to effective water measurement practices for better water management: Denver, Colo., U.S.
Department of the Interior, Bureau of Reclamation, Water Resources Research Laboratory, accessed February 9, 2006, at http://www.usbr.gov/pmts/hydraulics_lab/ pubs/wmm/

Conservation and Survey Division, University of Nebraska -Lincoln (CSD), 1996, Bedrock geology - Bedrock.e00: Lincoln, Nebraska, Conservation and Survey Division, University of Nebraska-Lincoln, accessed on February 10, 2006, at http://csd.unl.edu

Druliner, A.D., Chen, H.H., and McGrath, T.S., 1996, Relations of nonpoint-source nitrate and atrazine concentrations in the High Plains aquifer to selected explanatory variables in six Nebraska study areas: U.S. Geological Survey WaterResources Investigations Report 95-4202, 51 p.

Dugan, J.T., and Zelt, R.B., 2000, Simulation and analysis of soil-water conditions in the Great Plains and adjacent areas, Central United States, 1951-80: U.S. Geological Survey Water-Supply Paper 2427, 81 p.

Fenneman, N.M., 1946, Physical divisions of the United States: U.S. Geological Survey, scale 1:7,000,000, 1 sheet.

Flowerday, C.A., Kuzelka, R.D., Pederson, D.T., 1998, The groundwater atlas of Nebraska (2d ed.): University of Nebraska-Lincoln, Conservation and Survey Division, Resource Atlas No. 4A, 44 p.

Frenzel, S.A., Swanson, R.B., Huntzinger, T.L., Stamer, J.K., Emmons, P.J., and Zelt, R.B., 1998, Water quality in the Central Nebraska Basins, Nebraska, 1992-95: U.S. Geological Survey Circular 1163, 33 p.

Fulford, J.M., 1998, User's guide to the U.S. Geological Survey Culvert Analysis Program, Version 97-08: U.S. Geological Survey Water-Resources Investigations Report 98-4166, 70 p.

Gilliom, R.J., Hamilton, P.A., and Miller, T.L., 2001, The National Water-Quality Assessment Program-entering a new decade of investigations: U.S. Geological Survey Fact Sheet 071-01, 6 p.

Geolytics, Inc., 2001, Census CD 2000 Blocks: Brunswick, N.J., Geolytics, compact disc.

Helgesen, J.O., Zelt, R.B., and Stamer, J.K., 1994, Nitrogen and phosphorus in water as related to environmental setting in Nebraska: Water Resources Bulletin, v. 30, no. 5, p. 809-822.

Hitch, D.E., Hull, S.H., Walczyk, J.D., Miller, J.D., and Drudik, R.A., 2005, Water resources data, Nebraska, water year 2004: U.S. Geological Survey Water-Data Report NE-04-1, 671 p.

Huntzinger, T.L., and Ellis, M.J., 1993, Central Nebraska river basins, Nebraska: Water Resources Bulletin, v. 29, no. 4, p. 533-574. 
Lapham, W.W., Wilde, F.D., and Koterba, M.T., 1997, Guidelines and standard procedures for studies of ground-water quality — selection and installation of wells, and supporting documentation: U.S. Geological Survey Water-Resources Investigations Report 96-4233, 51 p.

Miller, J.A., and Appel, C.L., 1997, Ground water atlas of the United States-Kansas, Missouri, and Nebraska: U.S. Geological Survey Hydrologic Atlas 730-D, 24 p.

National Agricultural Statistics Service (NASS), 2003, Agricultural chemical use database, accessed October 6, 2005, at http://www.pestmanagement.info/ nass/app_statcs2_state.cfm

National Agricultural Statistics Service (NASS), 2004a, National Agriculture Statistics Service's 1:100,000-Scale 2003 Cropland Data Layer, A Crop-Specific Digital Data Layer for Nebraska, March 14, 2003: U.S. Department of Agriculture, National Agricultural Statistics Service, CD-ROM (official website: http://www.nass.usda.gov/ research/Cropland/SARSla.htm).

National Agricultural Statistics Service (NASS), 2004b, Nebraska biotechnology varieties chemical usage, 2003: U.S. Department of Agriculture, National Agricultural Statistics Service, accessed October 6, 2005, at http://www.nass.usda.gov/ne/special/agchem04.pdf

National Climatic Center, 2005, Climatography of the United States, no. 84, 1971-2000: Asheville, N. Car., NOAA National Climatic Center, Daily Station Normals - CLIM84 data available on the web, accessed October 6, 2005, at http://www.ncdc.noaa.gov/DLYNRMS/ dnrm? coopid $=251825$

Rus, D.L., Dietsch, B.J., and Simon, Andrew, 2003, Streambed adjustment and channel widening in eastern Nebraska: U.S. Geological Survey Water-Resources Investigations Report 03-4003, 64 p.

Soenksen, P.J., Miller, L.D., Sharpe, J.B., and Watton, J.R., 1999, Peak-flow frequency relations and evaluation of the peak-flow gaging network in Nebraska: U.S. Geological Survey Water-Resources Investigations Report 99-4032, $47 \mathrm{p}$.

Spalding, R.F., Burbach, M.E., and Exner, M.E., 1989, Pesticides in Nebraska's ground water: Ground Water Monitoring Review, v. 9, no. 4, p. 126-133.

Stamer, J.K., and Wieczorek, M.E., 1995, Pesticides in streams in central Nebraska: U.S. Geological Survey Fact Sheet FS-232-95, 4 p.
Stark, J.R., Andrews, W.J., Fallon, J.D., Fong, A.L., Goldstein, R.M., Hanson, P.E., Kroening, S.E., and Lee, K.E., 1996, Water-quality assessment of part of the Upper Mississippi River Basin, Minnesota and Wisconsin-environmental setting and study design: U.S. Geological Survey Water-Resources Investigations Report 96-4098, 62 p.

Tanner, D.Q., and Steele, G.V., 1991, Ground-water quality in the Nemaha Natural Resources District, southeastern Nebraska, 1989: U.S. Geological Survey Water-Resources Investigations Report 90-4184, 52 p.

U.S. Census Bureau, 2000, American fact finder: U.S. Census Bureau, accessed October 6, 2005, at http://factfinder.census.gov/

U.S. Department of Agricultural, Natural Resources Conservation Service, 2002, Soil Survey Geographic (SSURGO) database for Colfax County, Nebraska: Fort Worth, Texas, U.S. Department of Agriculture, Natural Resources Conservation Service, assessed on February 8, 2006, at http://www.ftw.nrcs.usda.gov/ssur_data.html

U.S. Geological Survey, 1999, ERF1-Enhanced River Reach File 1.2 (version 1.2, August 01, 1999): U.S. Geological Survey Open-File Report 99-457, scale 1:500,000, accessed December 7, 2005, at http://water.usgs.gov/lookup/ getspatial?erfl

U.S. Geological Survey, 2002, Elevation Derivatives for National Applications (EDNA): USGS NED-H data available on the web, accessed September 26, 2002, at http://edna.usgs.gov/

U.S. Geological Survey, 2003, Maple Creek watershed selected for a National water-quality study: U.S. Geological Survey Fact Sheet 083-03, 2 p.

U.S. Geological Survey, 2005, National Water Information System-historical ground-water data for Nebraska: accessed May 25, 2005, accessed October 6, 2005, at http://waterdata.usgs.gov/ne/nwis/gw/

University of Nebraska-Lincoln, Conservation and Survey Division, 1953, Logs of test holes, Dodge County, Nebraska: University of Nebraska, Conservation and Survey Division, Test Hole Report, 45 p.

Zelt, R.B., 1996, Basin-level habitat characteristics of selected streams in central Nebraska: U.S. Geological Survey OpenFile Report 96-361, 25 p. 
Prepared by Publications Service Centers 3 and 1

Graphics by Timothy W. Auer (PSC 3)

Layout and design by Ann Marie Squillacci (PSC 1)

For more information concerning the research in this report, contact:

Robert B. Swanson, Director

U.S. Geological Survey

Nebraska Water Science Center

5231 S. 19th Street

Lincoln, NE 68512-1271

or visit our Web site at:

http://ne.water.usgs.gov 
